\title{
A Feature-Based Theory OF Adverb Syntax ${ }^{*}$
}

\author{
Christopher Laenzlinger (Christopher.Laenzlinger@lettres.unige.ch)
}

\section{INTRODUCTION}

This paper is a comparative study of adverb distribution in Romance (mainly French) and Germanic (mainly German and English) within the feature-based theory of adverb syntax (Alexiadou 1997, Cinque 1999, Laenzlinger 1996, 1998). In this framework adverbs merge as specifiers of clause-internal functional projections. Alternatively, Ernst (2002) proposes a scope-based theory of adverb distribution. He argues against the feature-based theory by giving pieces of evidence against the uniqueness of adverb position and the left-to-right linearity of adverb co-occurrences. The two issues are illustrated in the following examples:

(1) a. (Amicalement,) Jean (,amicalement,) a (amicalement) salué (amicalement) le Friendlily Jean friendlily has friendlily greeted friendlily the professeur (amicalement).

professor friendlily

'Jean friendlily greeted the professor'

b. (*Déjà), Jean (*,déjà,) a (déjà) salué ( ??déjà) le professeur (*déjà). Already Jean already has already greeted already the professor already 'Jean already greeted the professor'

(2) a. Jean l'a refait rapidement souvent maintenant.

Jean it-has redone quickly often now

'Jean now often quickly did it again'

b. Jean l'a maintenant souvent rapidement refait.

Jean it-has now often quickly redone

'Jean now often quickly did it again'

c. Jean l'a souvent gentiment fait de nouveau.

Jean it-has often kindly done again

'John often did it kindly again'

d. Jean l'a (de nouveau) souvent (de nouveau) gentiment fait.

Jean it-has again often again kindly done

'John often did it kindly again'

One can observe that the manner adverb amicalement in (1a) can occupy various positions within the clause, whereas the aspectual adverb déjà in $(1 \mathrm{~b})$ is confined to a single position. What differences between the two adverbs can account for the contrast in (1a-b)? The adverb amicalement differs from the adverb déjà in two ways. First, déjà is considered a "light" adverb in comparison with the "heavy" form amicalement. Second, the adverb déjà is

\footnotetext{
"I would like to thank Thierry Etchegoyhen, Sandra Schwab and Stéphanie Dürrleman for comments on the first draft of this paper. This work is part of my thesis d'habilitation à diriger des recherches defended on the $13^{\text {th }}$ of December 2002 at the University of Lille 3 (France).
} 
quantificational (quantification over time), while the adverb amicalement is qualificational (circumstantial).

In (2a-b) one can note that the postverbal sequence of adverbs is the mirror image of the preverbal sequence. This is unexpected under the view that adverbs are merged as left specifiers of specific projections and that the order [V AdvP] results from verb (projection) movement. Finally, in (2c-d) we have a clear case of scope ambiguity. The repetitive adverb de nouveau in postverbal position in (2c) has scope over the manner adverb, but may or not have scope over the frequency adverb. The scope relations are expressed linearly in the surface order possibilities in (2d).

Such issues will be discussed in this paper with respect to the feature-based theory of adverb syntax. This approach, relying on merging adverbs as unique left specifiers, will be compared with the scope-based theory of adverb distribution (Ernst 2002, Haider 2000, Frey 2000), which appeals to (multiple) adjunction and possibly right attachment of adverbs. I will tackle the question of the syntax-semantics interface of adverb distribution following a "tightfit" approach to adverb licensing, as compared with a "loose-fit" approach in Ernst's (2002) terms. According to the "tight-fit" approach, the position of the adverbs coincides with their interpretation in the sense that each class of adverb is assigned a single position in syntax, i.e. the specifier position of a specific semantically related functional projection. According to the "loose-fit" approach, the distribution of adverbs is regulated by their semantics in the sense that syntax provides a possible range of positions for adverbs and that their precise merging as adjoined elements is dictated by semantic principles, such as scope (under c-command).

The scope of the paper is to compare the distribution of adverbs within the three domains of the clause in French and German. It will be assumed that these two languages are subject to the same set of transformations. Verb movement will be analyzed as an instance of remnant/pied-piping VP-movement to the specifier of an inflectional/auxiliary projection (InflP/AuxP). Head-movement will be restricted to very local domains of the same categorical type. In addition to VP-raising, French and German share the property of argument scrambling of the the subject to Spec-SubjP and of the objects to specifiers of ObjP.

The aim of this paper is to show that the feature-based theory of adverb licensing is able to handle the problem of adverb order variation. The various positions of (some) adverbs will be explained by (i) distinct positions for adverb merger and (ii) different locations for verb (projection) movement and object scrambling. As regards the second point, I will postulate for French and German the same core of clause structure (principles), which contains a base of functional projections, morpho-functional projections like InflP/AuxP and derived argument positions (SubjP, ObjP). French and German clause minimally differ in (their parameter setting for) (i) the location of InflP/AuxP and ObjP within the clause structure and (ii) the (non) application of head-movement to Subj or C. These parametric differences account for the variations in the distribution of adverbs within the clause between French and German.

The paper is organized as follows. After the introduction in section 1, section 2 sets forth the theoretical background by introducing the mechanisms of feature checking/Criterion, phrase structure merging, and clause structure composition. In section 3, the distribution of adverbs in the middle field (henceforth Mittelfeld) is discussed for French (section 3.1) and German (section 3.2). Section 3.1.1 introduces the main structural properties of French, as such SVO order, generalized verb projection raising and short scrambling of arguments. Section 3.1.2 presents a discussion of the range of A'-positions (for adverbs) and A-positions (for arguments) in the Mittelfeld. Section 3.1.3 deals with the set of transformations in the Mittelfeld affecting the linear placement of adverbs. In section 3.2.1 the main properties of the German Mittelfeld are discussed in relation to the basic word order (OV vs. VO), VPraising, and high/low scrambling. In section 3.2.2 the positions of adverbs and scrambled 
arguments are identified on the basis of their respective ordering. The main transformations of the German Mittelfeld are presented, such as verb projection raising, argument and adverb movement. Section 4 deals with the distribution of adverbs in the Nachfeld, mainly in French and English, and includes a discussion of adverb interference in the VP-shell structure. In section 4.1 the order [V Adv Compl] is analyzed with respect to different classes of adverbs and different types of complements. Section 4.2 is concerned with sentence-final adverbs, focussing on sequences of postverbal adverbs and mirror image ordering (triggered by a "snowballing" sort of movement). Section 5 deals with the occurrence of adverbs in the Vorfeld, mainly in French and German. In section 5.1, the sequences [Adv Subj Aux/V] and [Subj Adv Aux/V] are analyzed in Romance and English from a comparative point of view. Section 5.2 deals with adverb preposing in German in relation to the phenomenon of remnant and pied-piping VP-topicalisation in German. Finally, section 6 contains the conclusion.

\section{THEORETICAL BACKGROUND}

There exist several theories of adverb distribution in generative grammar. For the most part, they address the question of the syntax-LF/PF interface, which is certainly relevant to adverb distribution. Apart from purely phonological, semantic or stylistic approaches, there are three main trends in the syntax-semantics analysis of adverbs within the framework of the Principles \& Parameters theory : (i) the theory of predication (Roberts 1985, Rochette 1990); (ii) the scope-based theory (Haider 2000, Ernst 2002, Frey 2000); (iii) the feature-based theory (Travis 1988, Laenzlinger 1996, 1998, Alexiadou 1997, Cinque 1999). Arguments against the theory of predication are provided in Laenzlinger (1998: 69-72). This paper focuses on the feature-based theory of adverb licensing in which a one-to-one relation between the position (specifier) and the interpretation of adverbs is established. By comparison, the scope-base theory specifies possible positions for adverbs with respect to lexical selection and independent semantic rules. Put simply, the feature-based theory stresses the role of syntax in the semantics of adverbs, while the scope-based theory stresses the role of semantics in the syntax of adverbs.

The feature-based theory relies mainly on Checking Theory (Chomsky 1995). Thus, adverbs must occur in a checking configuration, essentially in a Spec-head relation with the appropriate head (Laenzlinger 1996, 1998, Alexadiou 1997, Cinque 1999) for full adverbs and head-head relation for clitic adverbs. The features to be checked on adverbs are not formal (uninterpretable) features, but substantive (interpretable) ones. They are checked at the root, by means of pure Merge, similarly to thematic or selectional features. Laenzlinger (1998: 83-88) distinguishes adverbs that are subject to Checking Theory (qualificational adverbs) from those that are subject to the system of Criteria (quantificational adverbs licensed by means of the Adv-Criterion). The latter adverbs stand for operators in specifier positions, as shown by the relativized minimality effects on combien extraction (Obenauer 1983, Rizzi 1990) in (3).

(3) *Combien as-tu probablement/souvent/presque/à peine/beaucoup lu $[t]$ de livres How many has-you probably /often /almost /hardly/a lot read of books de Chomsky?

of Chomsky?

'How many books of Chomsky did you probably/often/almost/hardly read /a lot?'

In addition, these adverbs, like neg/wh/foc-operators, are "frozen" in their licensing position once they have satisfied the Adv-Criterion. In other words, they cannot be displaced from their base position to a fronted position, as illustrated in (4). 
(4) a. Tu as beaucoup/à peine/presque dormi.

You have a lot /hardly/almost slept

'You almost/hardly slept /a lot'

b. *Beaucoup/à peine/presque, tu as dormi.

A lot /hardly/almost you have slept

The possibility of having probablement 'probably' and souvent 'often' in sentence-initial position in (5b) does not result from movement of the adverb. As will be discussed in section 5.1.2, these adverbs are in their root positions, where they are licensed.

(5) a. $\mathrm{Tu}$ as probablement/souvent dormi.

You have probably/ often slept

'You probably/often slept'

b. Probablement/souvent, tu as dormi.

'Probably/often you slept'

Work by Jackendoff (1972), McConnell-Ginet (1982), Cinque (1999) and Ernst (2002) gives rise to a relatively complete typology of adverbs. The classes of adverbs relevant to this paper are given in (6). Each class is exemplified by an adverb in English, French and German.

\section{(6) - Sentence adverbs:}

1. Discourse adverbs (conjunctive adverbs): cependant/however/jedoch

2. Form adverbs: précisément/precisely/gerade

3. Mood adverbs:

(a) Evaluative adverbs: heureusement/fortunately/glücklicherweise

(b) Speech-act adverbs: franchement/frankly/offen gestanden

(c) Evidential adverbs: assurément/assuredly/sicherlich

4. Domain adverbs: logiquement/logically/logischerweise

5. Modal adverbs:

(a) epistemic: probablement/probably/wahrscheinlich

(b) (ir)realisis: peut-être/maybe/vielleicht

(c) necessity: nécessairement/necessarily/notwendigerweise

(d) possibility: éventuellement/possibly/möglicherweise

(e) volitional: volontiers/willingly/gern

(f) obligation: inévitablement/inevitably/unvermeidlich

(g) ability/permission: intelligemment/cleverly/scharfsinnig

6. Time adverbs: récemment/recently/kürzlich

7. Aspect I adverbs:

(a) habitual: habituellement/usually/gewöhnlicherweise

(b) repetitive: à nouveau/again/wieder

(c) frequentative: souvent/often/oft

(d) celerative: rapidement/quickly/schnell

(e) perfective : (ne) plus, toujours/no longer, always/nicht mehr, immer

(f) continuative: encore/still/noch

(g) retrospective: (just) leben 


\section{- VP adverbs:}

8. Aspect II adverbs:

(a) proximative: presque/almost, à peine/hardly, fast/kaum

(b) Q-measure: beaucoup/much, assez/enough, viel/genug

(c) completive: complètement/completely/ganz,völlig

9. Circumstantial (manner/instrument/result...) adverbs:

(a) Verb-oriented adverbs: péniblement/painstakingly, correctement/correctly, mühsamerweise/korrekt

(b) Object-oriented adverbs: entièrement/entirely, lourdement/heavily ganz/schwerfällig

Adverbs in English, French and German are full maximal lexical categories (Adv -> AdvP), which can be modified (very often, rather slowly). A few of them can take a PP complement (independently of, similarly to). Some adverbs in French are weak forms (bien 'well', mal 'badly') whose distribution is very constrained (e.g. J'ai bien dormi 'I slept well' vs. ?? J'ai dormi bien/*Bien, j'ai dormi). They seem to be subject to an incorporation requirement, which distinguishes them from strong adverbial forms.

Within the feature-base theory, each class of adverb in (6) is confined to a single position, which is identified as the specifier position of a corresponding semantically related functional projection. Such an approach readily fits in with the LCA (Kayne 1994) conception of phrase structures, as advocated by Alexiadou (1997) and Cinque (1999). Specifiers are unique left-branching adjoined phrases. In Kayne's system multiple adjunction is banned, as well as right attachment of specifier. The only possible configuration is [Spec $\mathrm{X}^{\circ} \mathrm{Compl}$. Adverbs are adjoined specifiers attached to the left. Linearly they precede the head with which they are associated. Chomsky (1995) proposes the system of Bare Phrase Structure as an alternative way of deriving phrase structures from non-primitive entities. Chomsky's proposal has shortcomings opposite to Kayne's antisymmetry system. Multiple specifiers are allowed (by successive set-Merge), and adjunction is available (by pair-Merge). According to this model of phrase structure, adverbs could be either specifiers or adjoined phrases. Adjunction has been tentatively formalized following the Principles \& Parameters model of X'-theory (see May 1985, Chomsky 1986). For instance, the structure preserving constraint forces XP to adjoin to maximal projections and $\mathrm{X}^{\circ}$ to heads. Adjunction to the $\mathrm{X}^{\prime}$-level is not permitted, contrary to what Ernst (2002) proposes in his scope-based theory of adverbs. In this paper, however, I follow the feature-based theory of adverbs, without free adjunction, respecting the LCA.

If adverbs are unique specifiers of semantically related projections, the clause structure can be assigned a large number of functional projections, as proposed by Cinque (1999). There is a potential slot in the clause structure for each class of adverbs given in (6) following the hierarchy of functional projections in (7) given by UG. In the absence of adverbs (or lexicalized heads) the functional projections are assigned a default value. 
(7)

$\left[\right.$ Frankly/Franchement Mood $_{\text {speech act }}>$ [unfortunately/malheureusement $\operatorname{Mood}_{\text {evaluative }}>$ [apparently/apparemment Mood $_{\text {evidential }}>\left[\right.$ probably/probablement $\operatorname{Mod}_{\text {epistemic }}>$ [once/autrefois $\mathrm{T}_{\text {past }}>$ [then/ensuite $\mathrm{T}_{\text {future }}>$ [maybe/peut-être $\operatorname{Mod}_{\text {(ir)realisis }}>$ $\left[\right.$ necessarily/nécessairement $\operatorname{Mod}_{\text {necessity }}>\left[\right.$ possibly $\operatorname{Mod}_{\text {possibility }}>$ [deliberately/intentionnellement $\operatorname{Mod}_{\text {volitional }}>$ [inevitably/inévitablement $\operatorname{Mod}_{\text {obligation }}>$ [cleverly/intelligemment $\mathrm{Mod}_{\text {ability/permission }}>\left[\right.$ usually/habituellement Asp $\mathrm{p}_{\text {habitual }}>[$ again/de nouveau $\mathrm{Asp}_{\text {repetitive }}>\left[\right.$ often/souvent $\mathrm{Asp}_{\text {frequentative }}>\left[\right.$ quickly/rapidement $\mathrm{Asp}_{\text {celerative }}>$ [already/déjà $\mathrm{T}_{\text {anterior }}>\left[\right.$ no longer/plus Asp $\mathrm{p}_{\text {perfect }}>\left[\right.$ still/encore Asp $_{\text {continuative }}>$ [always/toujours Asp perfective $>[$ just/juste Asp retrospective $>[$ soon/bientôt Asp proximative $>$ [briefly/brièvement $\mathrm{Asp}_{\text {durative }}>$ [typically/typiquement $\mathrm{Asp}_{\text {generic/progressive }}>[$ almost/presque Asp $_{\text {prospective }}>\left[\right.$ completely/complètement Asp SgCompl etive(I) $>\left[\right.$ all/tout Asp $p_{\text {PICompl }}>[$ well/bien Voice $>\left[\right.$ fast/vite Asp $\mathrm{f}_{\text {celerative(II) }}>\left[\right.$ completely/complètement $\mathrm{Asp}_{\text {SgCompletive(II) }}>[$ again/de

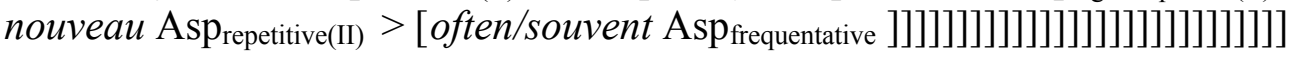

In the spirit of Giorgi \& Pianesi (1997), Laenzlinger (2000) proposes that the clause be assigned a minimal semantically legitimate structure, namely (8).

$$
\text { Mood }>>\text { Mode }>>\text { Tense }>>\text { Aspect }_{\text {high }}>>\text { Aspect }_{\text {low }}>>v>\mathrm{V}
$$

The order of projections inside MoodPs, ModPs and AspPs is pre-established by the geometry of feature matrices associated with each major functional head. The set of features associated with the heads in (9) is precompiled in the Numeration as to the hierarchical organization among them. In the case of co-occurrences of several Mood, Mode, and Aspect phrases, as in the co-occurrences of adverbs, the clause structure is organized into a hierarchy according to the feature geometry in (9).

$$
\text { (9) } \begin{array}{ll}
\text { MoodP }>> & \text { ModeP } \\
\text { F1=speech-act } & \text { F1=epistemic } \\
>\text { F2=evaluative } & >\text { F2=irrealisis } \\
>\text { F3=evidential } & >\text { F3=necessity } \\
& >\text { F4= possibility } \\
& >\text { F5 }=\text { =volitional }
\end{array}
$$

$$
\begin{array}{ll}
\text { AspP(high) }>> & \text { Asp(low) } \\
\text { F1=habitual } & \mathrm{F} 1=\text { perfect(I) } \\
>\mathrm{F} 2=\text { repetitive } & >\mathrm{F} 2=\text { continuative } \\
>\mathrm{F} 3=\text { frequentative } & >\mathrm{F} 3=\text { perfect(II) } \\
>\mathrm{F} 4=\text { celerative } & >\mathrm{F} 4=\text { retrospective } \\
& >\mathrm{F} 5=\text { proximative } \\
& >\mathrm{F} 6=\text { durative } \\
& >\mathrm{F} 7=\text { generic/progressive } \\
& >\mathrm{F} 8=\text { prospective } \\
& >\mathrm{F} 9=\text { completive } \\
& >\text { etc. }
\end{array}
$$

I assume that the clause structure proposed by Cinque (1999) is potentially available in the case of co-occurrences of adverbs, although the minimal functional structure required by the semantics of full propositions (i.e. Event $>$ Process $>$ Activity/state) is the one given in (8).

Kayne/Cinque's model of phrase and clause structure requires a certain number of transformations (movement) to account for the right placement of adverbs with respect to the head that licenses them. For instance, verb/auxiliary movement affects the linear placement of adverbs (Pollock 1989, Belletti 1990, Cinque 1999), as illustrated in (10) for French. 
(10) a. Jean mange probablement $[\mathrm{v} t]$ une pomme.

Jean eats probably an apple

'Jean is probably eating an apple'

b. Jean a mangé probablement $[\mathrm{v} t]$ une pomme.

Jean has eaten probably an apple

c. Jean a probablement $[$ Aux $t]$ mangé une pomme.

Jean has probably eaten an apple

'Jean probably ate an apple'

Ernst (2002:92-95) points out two issues that arise from the LCA approach to adverb placement. The first one is related to the identification of the various landing sites for movement; the second one is related to the various (morphological?) triggers of such movement. The present paper discusses these issues and proposes answers to the questions of landing site and trigger.

The next section will deal with the distribution of adverbs in the Mittelfeld of the clause. The clause can be divided in three domains, as indicated in (11). The Mittelfeld goes from the complementizer position (non included) to the VP-shell structure (non included). The prefield (henceforth Vorfeld) corresponds to the Comp-domain, which is assumed to be a rich complex structure following Rizzi (1997). Finally, the post-field (henceforth Nachfeld) is equated with the Larsonian VP-shell structure (see Chomsky 1995).

ForceP $>$ TopP $>$ Foc $\mathrm{P}>$ TopP $>$ FinP $>$ MoodP $>$ ModP $>$ NegP $>$ TP $>$ AspP $1>$ AspP $2>v \mathrm{P}>$ VP

VORFELD

MITTELFELD

NACHFELD

The analysis of adverbs in the French Mittelfeld undertaken in section 3.1.1 will focus on their distribution with respect to verbs, auxiliaries and floating quantifiers.

\section{ADVERBS IN THE MITTELFELD}

\subsection{French}

\subsubsection{General structural properties}

French is an SVO language displaying verb movement (V-to-I movement following Pollock's (1989) analysis). In accordance with the LCA specifiers are on the left of their head, while complements are on the right. The subject is moved from Spec- $\nu \mathrm{P}$ to its surface position, which is identified as Spec-TP by Chomsky (1995). Following the clause structure in (8) and (11), the specifier of TP is an adverbial position. I propose that a position different from SpecTP serve as the landing site for subject movement. Let us call this position Spec-SubjP, corresponding to the previous Spec-AgrsP. In terms of Checking Theory, the EPP-features to be checked by the subject do not occur on T, but on Subj. Object complements merge with the VP-shell structure, and as will be argued later, can undergo short movement out of VP. Negation (i.e. NegP) stands for the borderline between sentential adverbs and VP-adverbs. Sentential adverbs correspond to adverbs of mood, mode and aspect (high), while VP-adverbs include adverbs of aspect (low) and manner. 
Most importantly, verb movement is analyzed here differently from Pollock's (1989) Vto-I movement (head movement). In the spirit of Koopman \& Szabolcsi (2000) I propose that V-to-I movement be reduced to an instance of remnant/pied-piping VP-movement. Headmovement remains a very constrained operation, restricted to projections of the same categorial label, that is, $v$ to V (VP-layer), Aux to I (IP-layer), Fin to Force (CP-layer). The analysis according to which verb movement to the IP-domain is an instance of XP-movement raises three issues: (i) What is the category displaced? (ii) What is the landing site? (iii) What motivates this movement? As regards the source issue in (i), I assume that the displaced constituent should be identified as $\mathrm{VP} / v \mathrm{P}$ (pied-piping verb movement), from where the objects can be extracted (remnant VP). As for the target issue in (ii), it is related to the trigger question in (iii). Movement results from the selectional relation between inflection (possibly lexicalized by an auxiliary) and VP. VP raises to Spec-InflP or AuxP to have its selectional features checked.

Let us consider the analysis of the French sentence Jean n'a probablement pas récemment souvent donné une pomme à Marie ('Jean probably did not recently often give an apple to Marie'). The indirect object merges as Compl of the participial verb (V), while the direct object merges as its Spec. As will be argued later, they raise to object-related projections, namely Spec-ObjP. The subject is root-merged as Spec- $v \mathrm{P}$ and raises to SpecSubjP to get its EPP-features checked. The auxiliary is merged as Aux and raises to Subj to check the agreement features of the subject. V raises to $v$ and the remnant $v \mathrm{P}$ moves to SpecAuxP. The adverb probablement merges as the specifier of ModeP, the adverb pas as the specifier of NegP, the adverb récemment as the specifier of TP and the adverb souvent as the specifier of AspP. The complete derivation is reproduced in (12). 
(12)

$\mathrm{CP}$

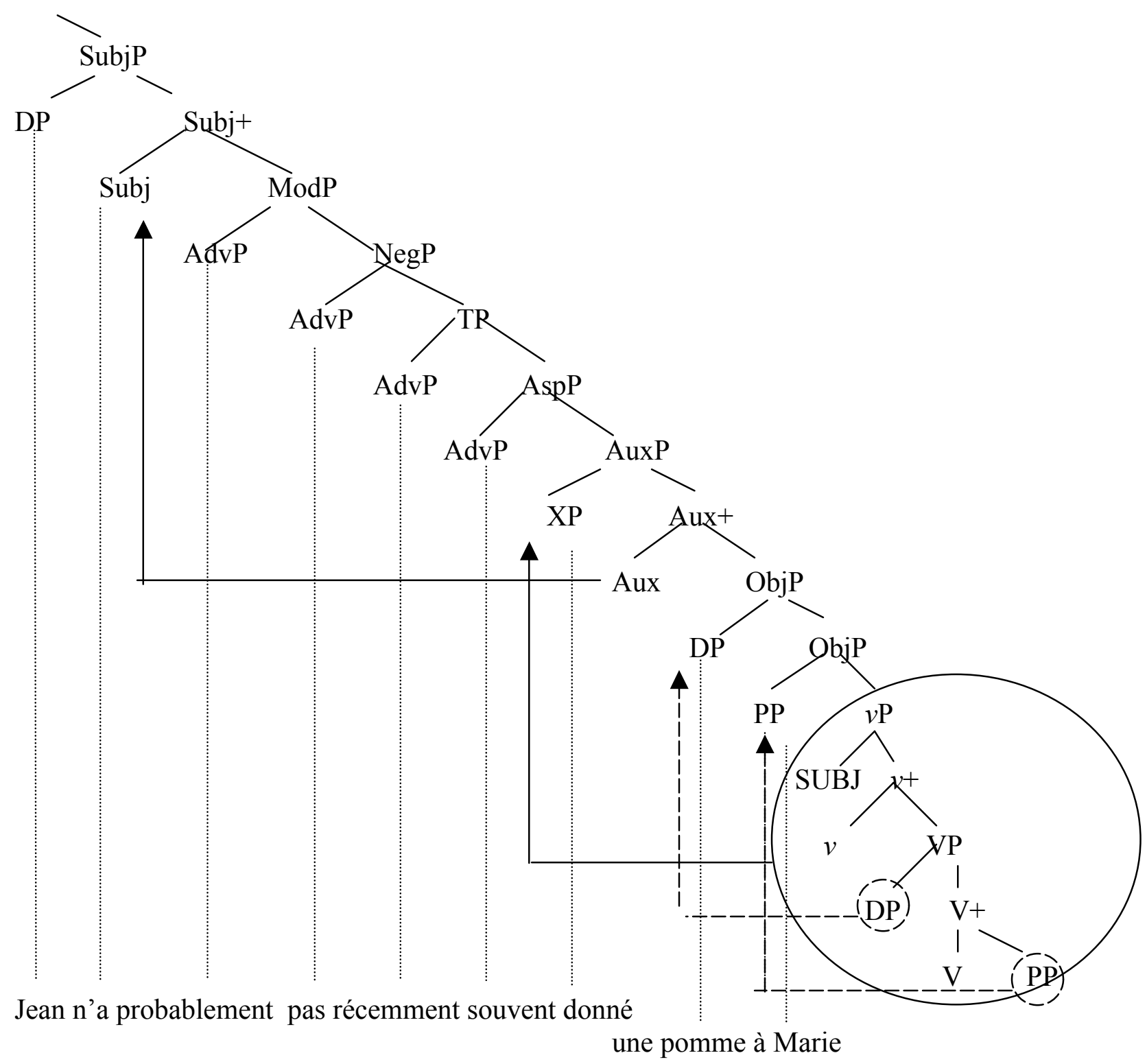

The above analysis has important shortcomings on the placement of adverbs with respect to the verb and the object. ${ }^{1}$ Take, for instance, a clause in simple tense: Jean ne donne probablement pas souvent une pomme à Marie ('John probably does not often give an apple to Mary'). The adverbs occur between the verb and its objects. In Pollock's (1989) analysis this configuration results from V-to-I movement. Within the present framework it results from VP-movement to Spec-InflP, as illustrated in (13). It is an instance of remnant VP-movement, since the objects have been first extracted from VP. The direct object DP and the indirect object PP both raise to object-related projections (i.e. Spec-ObjP). I also assume that the verb (V) in Spec-InflP raises to Subj as an instance of head-movement, as indicated in (13).

\footnotetext{
${ }^{1}$ The computational cost of remnant VP-movement in comparison with V-movement is balanced by the wide range of data that can be treated in Romance and Germanic by independent object movement, notably with respect to adverb placement (see section 3.1.2).
} 
(13)

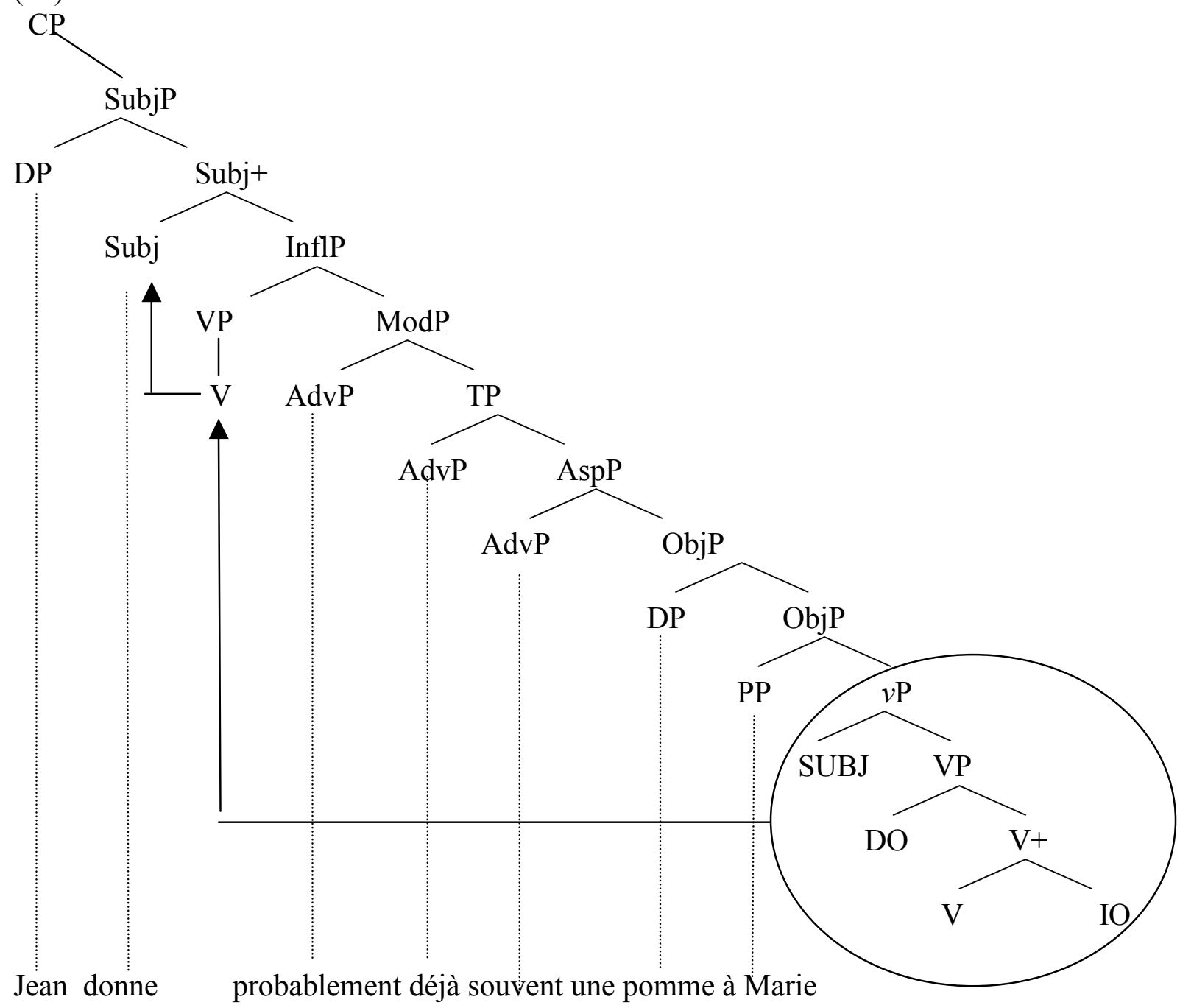

As will be shown in section 4 (Nachfeld), some adverbs can occur in a sentence-final position, as souvent in e.g. Jean ne donne probablement pas une pomme à Marie souvent 'Jean probably does not give an apple to Marie often'. Remnant and pied-piping VPmovement can account for this sentence-final configuration by means of object scrambling an verb projection raising (see section 4 for details).

As argued by Pollock (1989), verb movement applies to French, but not to English. In the English sentences in $(14 a-b)$ one can observe that the lexical verb occurs in a position following the adverbs, not only in compound tense, but also in simple tense.

(14) a. John has probably not recently often given an apple to Mary.

b. John probably already often gives an apple to Mary.

Following the VP-movement analysis, I assume that verb projection raising operates in French, but not in English. This parametric difference is illustrated by the contrast between (12)/(13) and (15). 
$(15)$

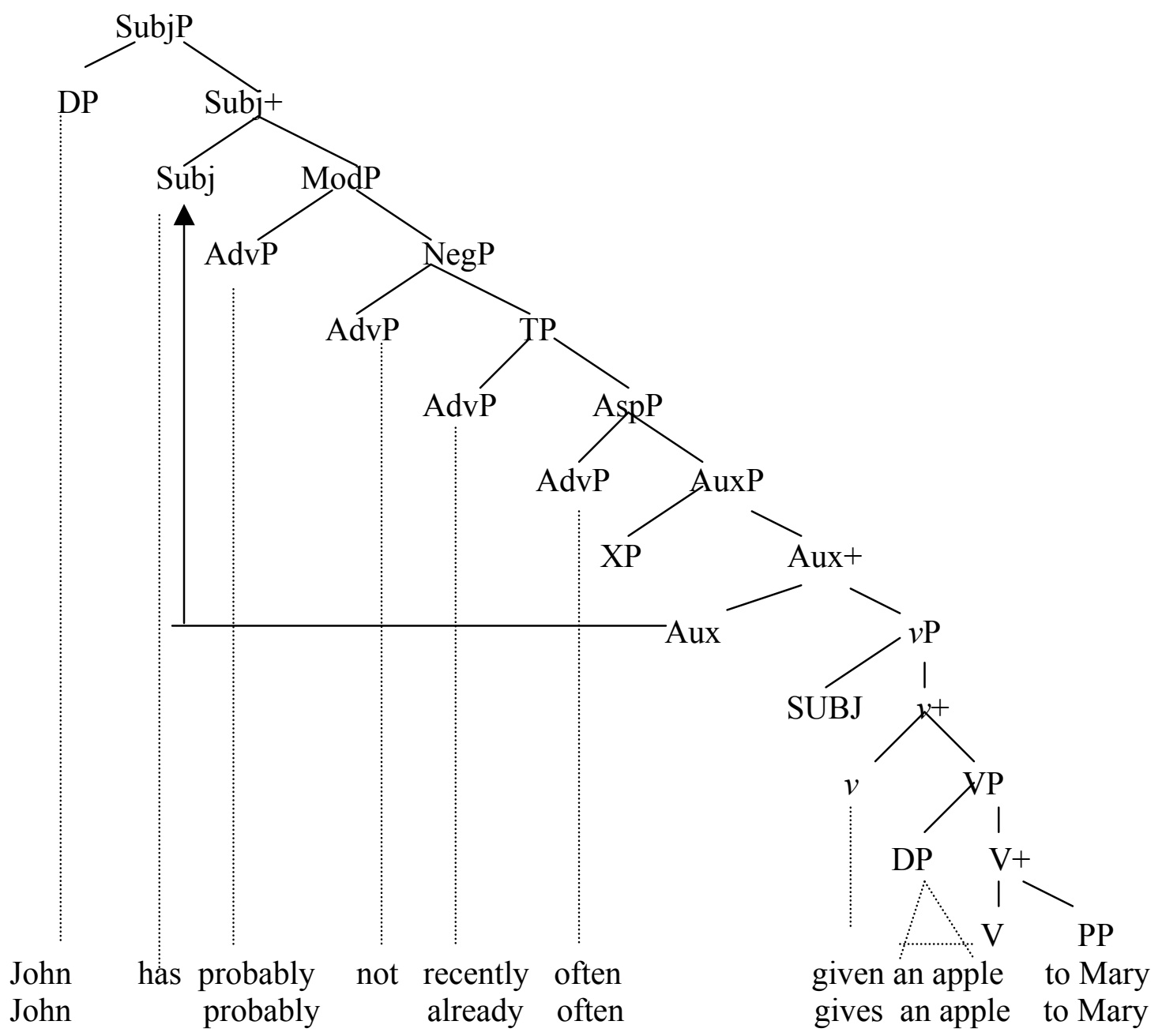

In the next section I will give further evidence in favor of (12/13) and (15) based on the various positions of adverbs with respect to the verb, the auxiliary and the objects.

\subsubsection{The French Mittelfeld}

The French Mittelfeld displays the adverb hierarchy presented in (7). Let us examine the adverb classes in (16).

(16) MoodP $\mathbf{P}_{\text {speech-act }}$ : franchement 'frankly'

$\mathbf{M o d P}_{\text {epistemic }}$ : probablement 'probably'

$\mathbf{M o d P}_{\text {volitional }}$ : spontanément 'willingly'

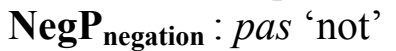

$\mathbf{T P}_{\text {anterior }}$ : récemment 'recently'

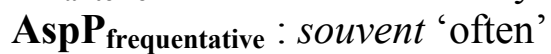

$\mathbf{A s p P}_{\text {proximative }}$ : à peine 'hardly'

MannP $\mathbf{P}_{\text {verb-oriented }}$ péniblement 'painstakingly'

Cinque's hierarchy of adverb-related functional projections predicts the left-to-right order in of adverbs in (17) for the Mittelfeld, as illustrated by the French examples in (18). All the 
adverbs occur in the structural space between the auxiliary and the participial verb (the socalled Mittelfeld). ${ }^{2}$

(17) MoodP $_{\text {speech-act }}<$ ModP $_{\text {epistemic }}<$ ModP $_{\text {volitional }}<\mathbf{N e g P}_{\text {negation }}<\mathbf{T P}_{\text {anterior }}<$

$\mathbf{A s p}_{\text {frequentative }}<\mathbf{A s p}_{\text {proximative }}<$ Manner $_{\text {verb-oriented }}$

(18) a. Jean a franchement probablement spontanément souvent mangé une pomme. Jean has frankly probably spontaneously often eaten an apple 'Frankly Jean probably spontaneously often ate an apple'

b. Jean n'a pas déjà souvent à peine mangé une pomme. Jean has not already often hardly eaten an apple 'Jean did not already often hardly eat an apple'

c. Jean n'a franchement probablement pas récemment souvent refait son travail. Jean has frankly probably not recently often redone his work 'Frankly Jean probably did not recently often do his work again'

d. Jean a spontanément souvent péniblement refait son travail. Jean has spontaneously often painstakingly redone his work 'Jean spontaneously often painstakingly did his job again'

The hierarchy in (17), exemplified in (18), relies on the clause structure in (19):

\footnotetext{
${ }^{2}$ There is a limit on the number of co-occurring adverbs in the Mittelfeld for reasons that do not concern internal (syntactic, semantic) factors, but external factors (human processing, prosody).
} 
(19)<smiles>C[Te]</smiles>

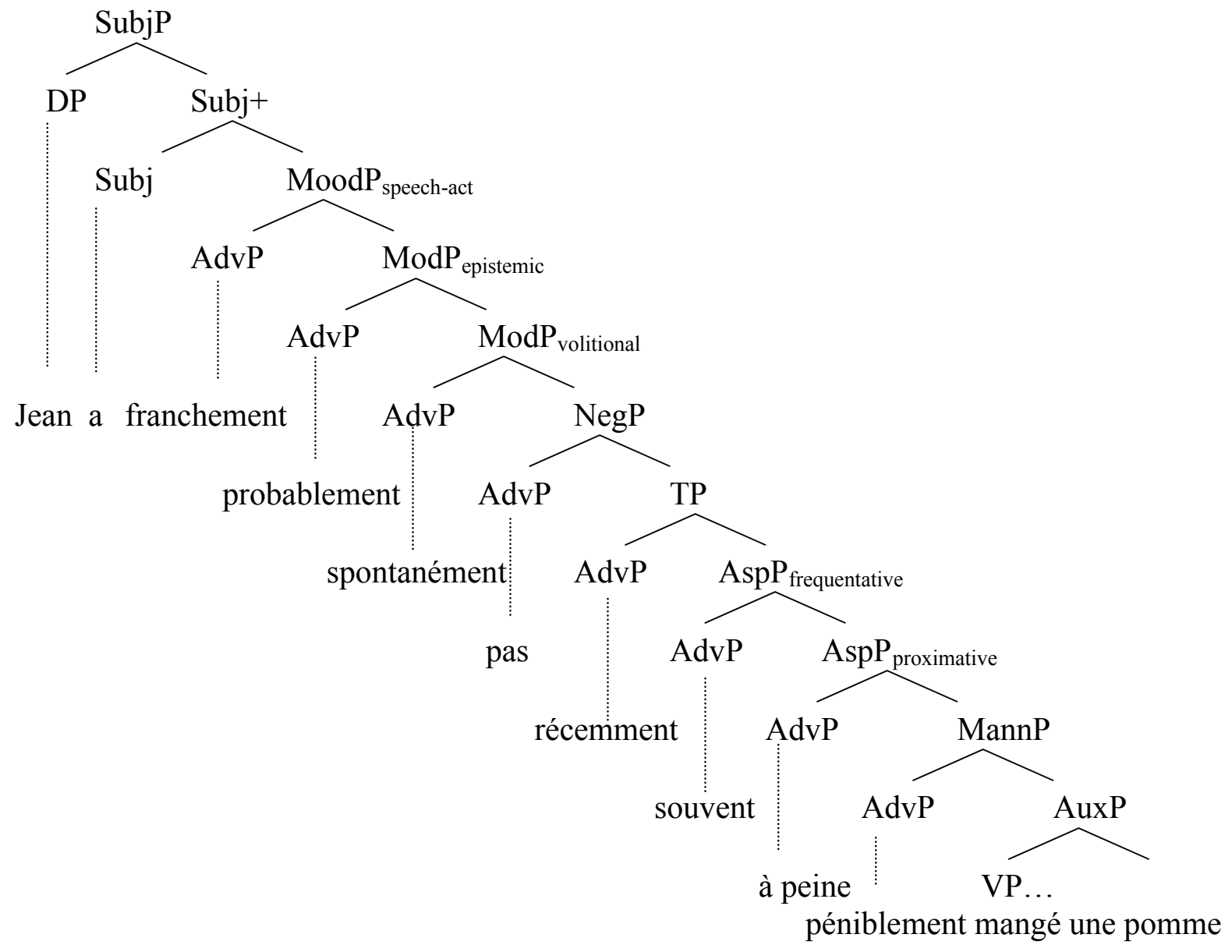

Ernst (2002) points out some cases that apparently violate Cinque's hierarchy in (17). They involve functional adverbs displaying what Ernst calls a "loose hierarchy". A particular example is the frequency adverb souvent, which seems to have a wide range of positions within the clause structure. For instance, it can occur below negation, as predicted by (17), but also above it. The two sentences in (20) are equally grammatical with the expected interpretation.

(20) a. Jean n'a pas souvent pleuré aux enterrements.

Jean has not often cried at the burials

'Jean did not often cried at the burials'

b. Jean n'a souvent pas pleuré aux enterrements.

Jean has often not cried at the burials

'Jean often did not cried at the burials'

As suggested by Cinque (1999:ch.4), the frequency adverb targets two possible positions: one is event-related ("there is a frequent event which is John not crying at the burials") and the other is process-related ("there is non-frequent event which is John crying at the burial"). The former position is situated higher than NegP (but lower than ModP) and the latter is realized as in (19). The structure of (20b) containing a modal adverb is given in (21). 
(21) [SubjP Jean n'a [ModP probablement [AspP souvent [ ${ }_{\text {NegP }}$ pas [AuxP [VP pleuré aux enterrements]]]]]]

Ernst (2002 : 357-66) points out that adverbs of the same functional class (say Asp $\mathrm{P}_{\text {high }}$ ), such as déjà 'already' and de nouveau 'again', may vary in their respective position, as shown in (22) for French.

(22) a. Jean a déjà de nouveau mangé une pomme.

Jean has already again eaten an apple

'Jean already ate an apple'

b. Jean a de nouveau déjà mangé une pomme.

Jean has again already eaten an apple

'Jean again already ate an apple'

Ernst takes facts like (22) as evidence against Cinque's tight-fit approach to adverb hierarchy. However, similarly to what is proposed for souvent, the repetitive adverb de nouveau can be merged in two different positions according to (7): one is below $\mathrm{TP}_{\text {anterior }}$ hosting déjà and the other is higher than $\mathrm{TP}_{\text {anterior. }}$ Hence, the order variation observed in (22) is expected.

In short, the so-called "loose hierarchy" only occurs when a given adverb is assigned two positions among the adverb-related functional projections of the clause. A well-known case is the ambiguous adverb intelligemment 'cleverly', which has a manner reading in (23a) and a (subject-oriented) factive/event-related reading in (23b).

(23) a. Jean n'a pas intelligemment répondu à la question.

Jean has not cleverly answered to the question

'Jean did not cleverly answered the question'

b. Jean n'a intelligemment pas répondu à la question.

Jean has cleverly not answered to the question

'Jean cleverly did not answered the question'

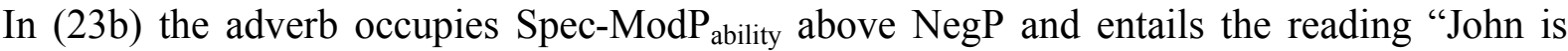
intelligent in not answering the question". In (23b) the adverb merges as Spec-MannP below NegP and is assigned the reading "John did not answer the question in an intelligent way". The two distinct positions of intelligemment are represented in (24).

(24) [SubjP Jean [ModP intelligemment [NegP pas [MannP intelligemment [AuxP [vP répondu à la question]

To sum up, French displays the following structural and derivational properties:

1. Short V-movement of auxiliaries and simple verb from Aux/Infl to Subj

2. $v \mathrm{P} / \mathrm{VP}$-raising to Spec-AuxP/InflP

3. Argument raising to Spec-SubjP (subject) and to Spec-ObjP (complements and floating quantifiers)

4. Ambiguous merger of adverbs like intelligemment, de nouveau, souvent, etc.

In the next section I will discuss the distribution of adverbs and arguments in the German Mittelfeld. I will show from a comparative point of view that the structural properties established for French also hold for German. The latter language differs from the former in that it displays high scrambling and verb movement to $\mathrm{C}$. 


\subsection{German}

\subsubsection{General structural properties}

In accordance with Kayne's (1994) LCA I follow the hypothesis that German is basically an SVO language. Thus, German is assigned the same minimal structural representation as French, as in (11) repeated in (25).

$$
\begin{gathered}
\text { ForcP }>\text { TopP }>\text { FocP }>\text { TopP }>\text { FinP }>\text { MoodP }>\text { ModP }>\text { NegP }>\text { AspP1 }>\text { AspP2 }>v \mathrm{P}>\text { VP } \\
\text { VORFELD }
\end{gathered}
$$

Despite basic SVO order in German, the verb can surface in a sentence-final position in some contexts, as for instance in the embedded clause in (26a).

(26) a. weil der Mann das Buch gelesen hat.

because the man the book read has

'because the man read the book'

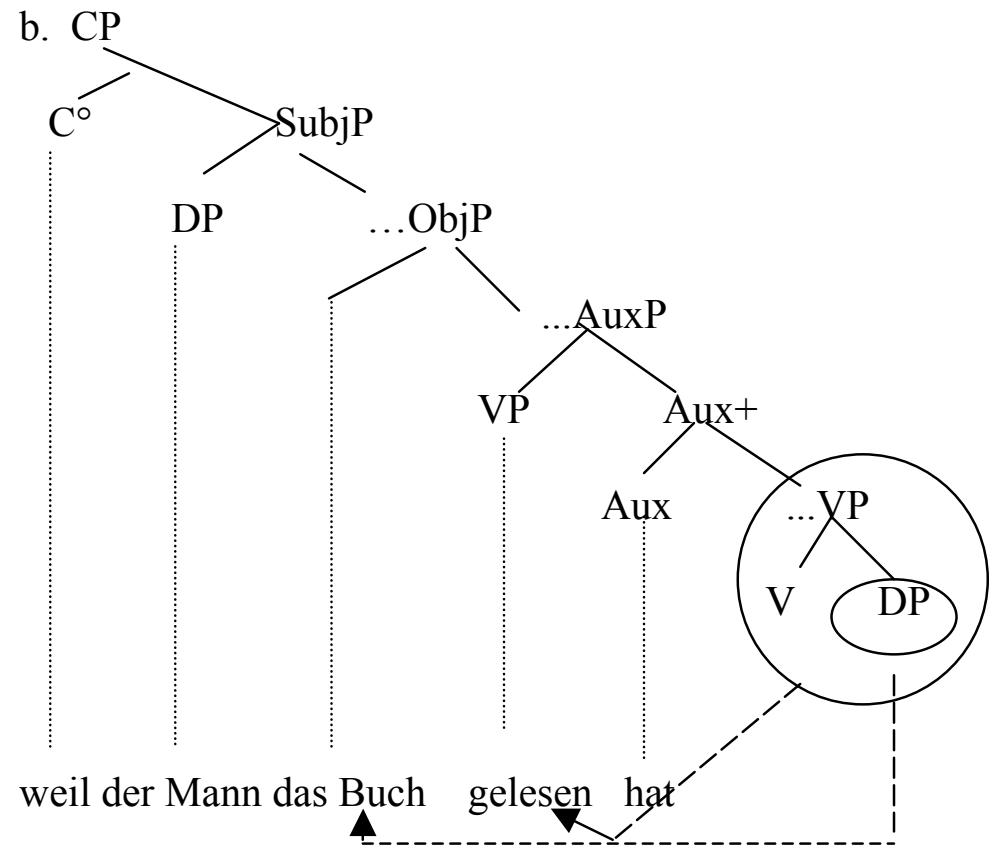

The tensed auxiliary occupies a sentence-final position, and is immediately preceded by the participial verb. The direct object occurs on the left of the two verbal forms. On the basis of the clause structure in (26b), the surface order is obtained after VP-movement to Spec-AuxP and object raising. VP-movement applies here in the same way as in French. The auxiliary remains on the right of the participle, because it does not raise to Subj. One of the parametric differences between German and French lies in Aux-to-Subj movement. As for object raising, it must be effected to Spec-ObjP. In simple tense, as in (27), VP-raising to InflP operates vacuously, since there is no lexical material in Infl.

(27) [CP Weil [SubjP der Mann [objp das Buch [InflP [vP las ] ] ] ] ] 
German also displays object scrambling past the subject (Frank, Lee \& Rambow 1991, Grewendorf \& Sternefeld 1990, Haider 1993, Moltmann 1991), as in (28a). Laenzlinger (1998:275-78) proposes that the object in a high scrambling position targets the specifier position of a topic phrase, which is not related to the CP-system, but to the IP-system. ${ }^{3}$ Laenzlinger calls this phenomenon "discourse topicalisation" (cf. "aboutness-topic", Frey 2000). The structure for (28a) is given in (28b).

(28) a. weil dieses Buch der Mann gelesen hat.

because this book the man read hat

'because the man read this book'

b. [CP Weil [TopP das Buch [SubjP der Mann [InflP [vP gelesen ] hat] ] ] ]

Consider now the occurrence of adverbs in the Mittelfeld. As proposed for French, the German clause structure contains the core functional projections in (25). Given the derived DP-positions in (26b) and (28b) the German Mittelfeld is assigned the structure in (29b) for the sentence in (29a) involving a modal adverb, negation, an aspectual adverb and a manner adverb.

(29) a. weil (diese Sonate) der Mann wahrscheinlich (diese Sonate) nicht oft gut because this sonata the man probably this sonata not often well gespielt hat.

played has

'because the man probably not often played the sonata well'

\footnotetext{
${ }^{3}$ There exist alternative analyses, such as an adjunction analysis (Müller \& Sternefeld 1993, Haider 1993) or an analysis in terms of A-position (Moltmann 1991, Haeberli 1993). Laenzlinger (op.cit) proposes that this topic position be a non-operator A'-position.
} 


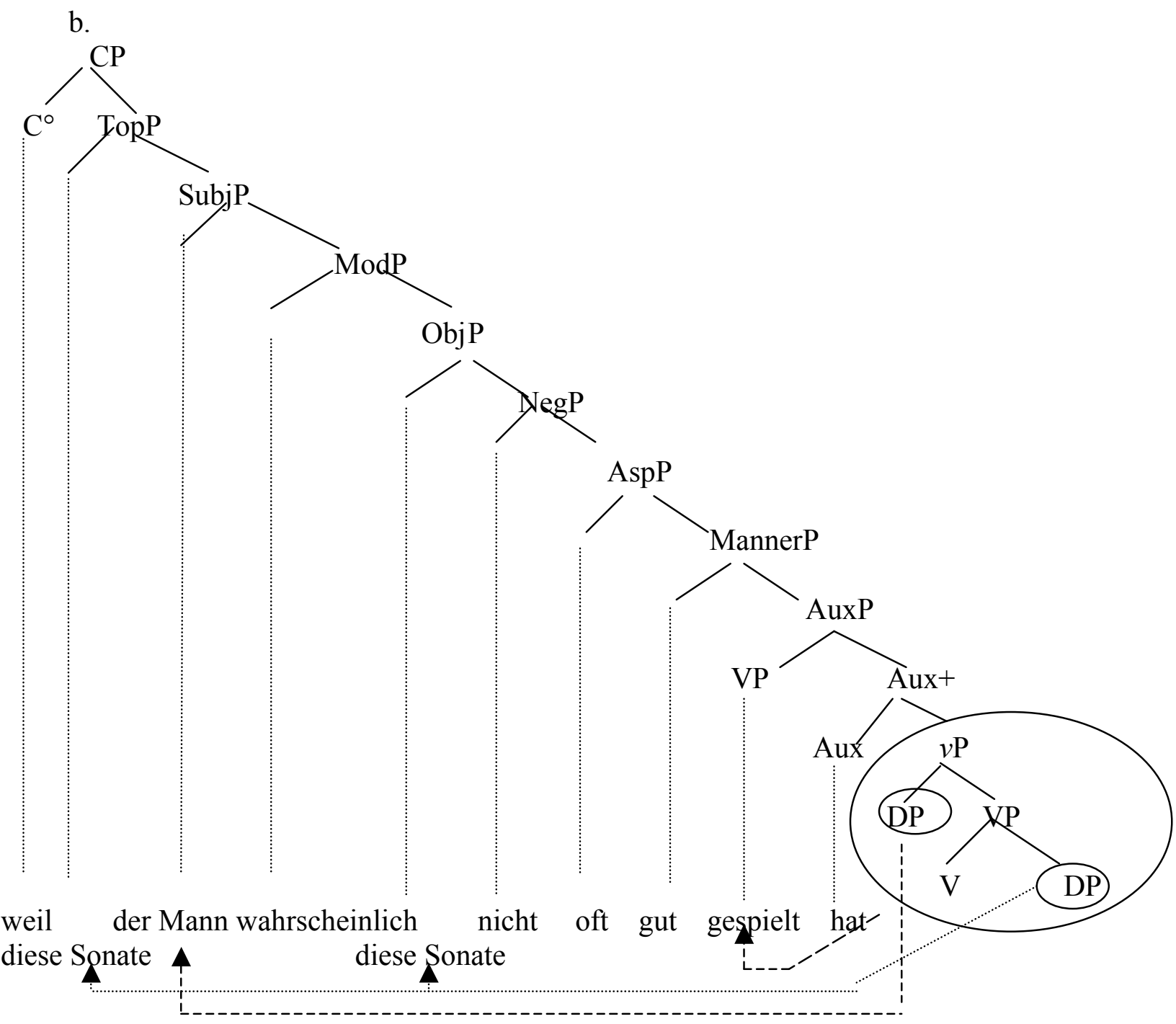

As shown in (30a), (tensed) clausal object complements remain in their postverbal position. This configuration derives from remnant VP-movement: the object complement is first extracted from the verbal projection before the $v \mathrm{P}$ raises to Spec-AuxP/InflP. The landing site of this object movement is a functional projection (maybe to be identified as AgroP) below AuxP. The relevant derivation is represented in (30b).

(30) a. weil der Mann gesagt hat, daß er kommen wird. because the man said has that he come will 'because the man said that he would come'

b. $\quad\left[\mathrm{CP}\right.$ weil $\left[\right.$ SubjP der Mann $\left[\right.$ AuxP $[\mathrm{vP} \text { gesagt }]_{\mathrm{i}}$ hat $\left[\mathrm{FP}=\mathrm{AgroP}\right.$ ? $[\mathrm{CP} \text { daß er kommen wird }]_{j}$ $\left.\left.\left.\left[\mathrm{vP} t_{\mathrm{i}}\left[\mathrm{CP} t_{\mathrm{j}}\right]\right]\right]\right]\right]$

The next section is devoted to a more detailed discussion of the interaction of adverb positioning with object scrambling in the Mittelfeld. 


\subsubsection{Positions for adverbs and scrambled arguments in the Mittelfeld}

Cinque's (1999) adverb hierarchy holds for German too, as shown in (32). These sentences are based on the hierarchy in (17), repeated in (31b), following the adverb classes in (31a). As far as the hierarchy of adverbs is concerned, the analysis proposed by Cinque (1999) in terms of a hierarchy of functional projections holds for German as well. In (32) are given some examples of the hierarchy in (17) repeated in (31b) on the basis of the adverb classes in (31a).

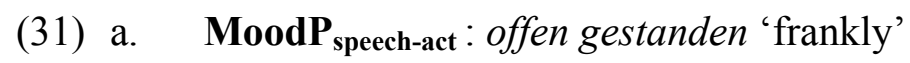

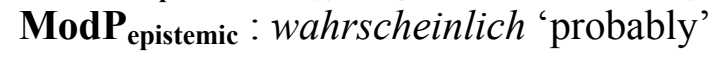

$\mathbf{M o d P}_{\text {volitional }}$ : freiwillig 'willingly'

NegP $P_{\text {negation }}$ : nicht 'not'

$\mathbf{T P}_{\text {anterior }}$ : schon 'already'

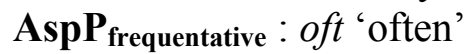

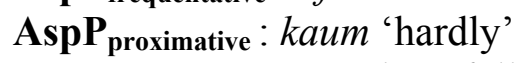

$\mathbf{M a n n P}_{\text {verb-oriented }}$ : schwerfällig 'painstakingly'

b. $\quad$ MoodP $_{\text {speech-act }}<$ ModP $_{\text {epistemic }}<$ ModP $_{\text {volitional }}<\mathbf{N e g P}_{\text {negation }}<\mathbf{T P}_{\text {anterior }}<$ $\operatorname{AspP}_{\text {frequentative }}<\operatorname{AspP}_{\text {proximative }}<$ MannP $_{\text {verb-oriented }}$

(32) (German equivalent of the French sentences in (18))

a. weil Hans offen gestanden wahrscheinlich freiwillig einen Apfel oft because Hans frankly probably spontaneously an apple often gegessen hat.

eaten has

'because frankly Hans probably spontaneously often ate an apple'

b. weil Hans einen Apfel nicht schon kaum gegessen hat.

because Hans an apple not already hardly eaten has

'because Hans did not already hardly ate an apple'

c. weil Hans offen gestanden wahrscheinlich seine Arbeit nicht schon beendet because Hans frankly probably his work not already finished hat

has.

'because frankly Hans probably did not already finish his work'

d. weil Hans freiwillig seine Arbeit oft schwerfällig beendet hat.

because Hans spontaneously his work often painstakingly finished has 'because Hans spontaneously often finished his work painstakingly'

The direct object complement, which has a specific (non-existential) interpretation (Diesing 1992, de Hoop 1993), is located above the negation and the VP-adverbs, but below the modal adverbs. Thus, the projection ObjP is situated between ModPs and NegP, as shown in (33). Each adverb merges as the specifier of its corresponding functional projection, namely MoodP $_{\text {speech-act }}$, ModP epistemic, $\mathrm{ModP}_{\text {volitional, }}$ NegP, TP, AspP $P_{\text {frequentative, }}$ AspP $P_{\text {proximative, }}$ MannP. 


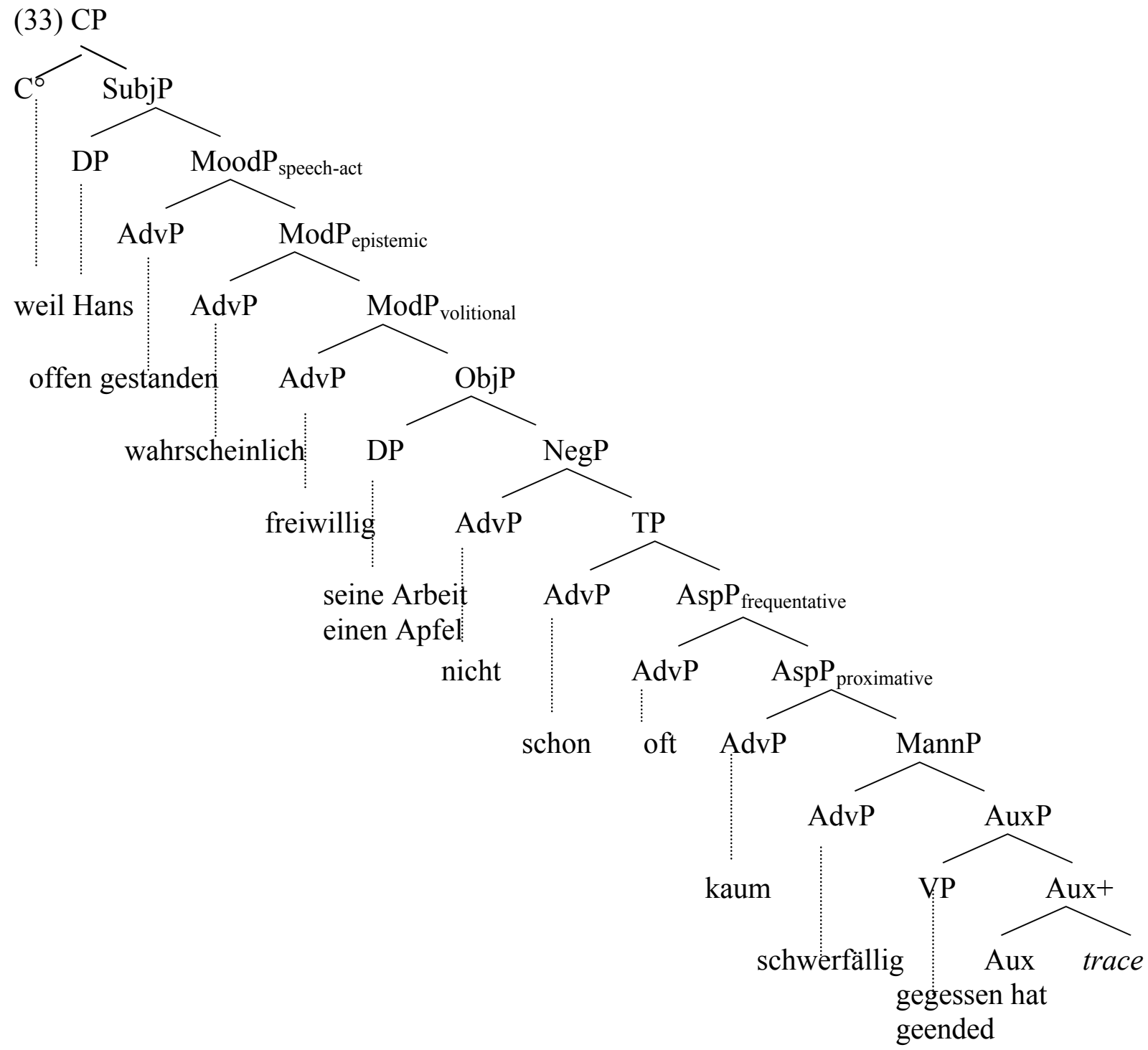

Most interestingly, one can observe that the structure and the derivation of compound tensed sentences minimally differ between French and German, namely in: (i) the positioning of ObjP and (ii) movement to Subj.

Like French, German displays cases of a "loose" adverb hierarchy with ambiguous items like oft or wieder. For instance, these adverbs can occur either above the negation or below it, as illustrated in (34).

(34) a. Hans hat (oft) nicht (oft) während der Beerdigung geweint.

Hans has often not often during the burials cried

'Hans (often) did not (often) cry at the burials'

b. Hans hat (wieder) seine Arbeit nicht (wieder) gemacht.

Hans has again his work not again done

'Hans (again) did not do his work (again)'

The adverbs in parenthesis in (34) can occur in two distinct structural positions. The aspectual adverbs can merge as the Spec of an aspectual projection (AspP) which is either higher or lower than NegP. 
The negation (i.e. NegP) functions as the borderline between sentential adverbs (proposition- and event-related adverbs) and VP-adverbs (process- and activity-related adverbs). It also serves to mark the domains of specific and non-specific interpretation (Diesing 1982, de Hoop 1983). Thus, the indefinite complement in (35a) below NegP and low AspP (oft) must have an existential reading. As represented in (35b), the non-specific DP occupies an object position lower than $\mathrm{NegP}$ and $\mathrm{AspP}_{\text {low }}$.

(35) a. weil Hans nicht oft Sonaten gespielt hat. because Hans not often Sonatas played has 'because Hans did not often played Sonatas'

b. weil [SubjP Hans [NegP nicht [AspP oft [ObjP Sonaten [AuxP [vP gespielt hat ] ] ] ] ]

As regards sentential adverbs, they must occur above the negation, although they can be placed in a position lower than the specific direct object, as illustrated in (36a-c).

(36) a. weil Hans die Sonate wahrscheinlich/offen gestanden (nicht) gespielt hat. because Hans the sonata probably /frankly (not) played has 'because Hans frankly/probably (did not) played the sonata'

b. weil Hans seine Arbeit freiwillig (nicht) gemacht hat. because Hans his work spontaneously (not) done has 'because Hans spontaneously (did not do) did his work'

The configuration $\left[\mathrm{Obj}_{\text {specific }} \mathrm{Adv}_{\text {sentential }} \mathrm{Neg}\right.$ ] derives from direct object raising to a high scrambling position. This position is situated at the top of the highest adverb-related functional projections, immediately below SubjP, as represented in (37).

(37) weil [SubjP Subject [ObjP Direct Object [MoodP offen gestanden [ModP wahrscheinlich [ [NegP nicht [Auxp [vP V ] Aux ] ] ] ] ]

Additional ObjP projections must be postulated in the Mittelfeld, among the adverb-related functional projections, to host the direct object in the various scrambled positions in (38).

(38) weil Hans (die Sonate) offen gestanden (die Sonate) wahrscheinlich (die Sonate) because Hans the sonata frankly the sonata probably the sonata oft (die Sonate) nicht gespielt hat.

often the sonata not played has

'because frankly Hans probably often did not play the sonata'

At least four distinct ObjP projections must be established in the Mittelfeld for (38), as represented in (39). ${ }^{4}$

\footnotetext{
${ }^{4}$ As pointed out by Frey (2000), the use of the indefinite quantifiers wer (someone nominative), wen ),

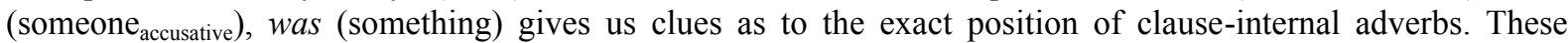
quantifiers are confined to a single (i.e. canonical) position in the Mittelfeld, which is between the complementizer and MoodP for the subject wer and between ModP and NegP for wen/was, as exemplified in (i). The subject position is identified as Spec-SubjP and the object position as Spec-ObjP between ModP and NegP.
}

(i) a. weil wer offen gestanden wahrscheinlich was gespielt hat. because someone frankly probably something played has 'because frankly someone probably played something' 
(39) weil [Subjp Hans [Objp die Sonate [MoodP offen gestanden[ObjP die Sonate [ModP wahrscheinlich [objp die Sonate [AspP oft [objP die Sonate [ ${ }_{\mathrm{NegP}}$ nicht [AuxP gespielt hat []]]]]]]]]

Consider now the placement of adverbs in the pre-subject domain of the Mittelfeld, as illustrated in (40)

(40) a. weil offen gestanden/wahrscheinlich/sorgfältigerweise ${ }^{5}$ Hans die Sonate gespielt because frankly/ probably/ carefully Hans the sonata played hat.

has

'because frankly/probably/carefully Hans played the sonata'

b. weil oft/*nicht/schwerfällig Hans die Sonate gespielt hat.

because often/*not/painstakingly Hans the sonata played has

'because often/*not/painstakingly Hans played the sonata'

One can observe that adverbs (except negation) can be scrambled in a pre-subject position, which is the same position as the one occupied by the scrambled object in (29a). Thus, adverbs can move from their position of interpretation to a topic position internal to the Mittelfeld, as represented in (41).

(41) [CP weil [TopP offen gestanden ${ }_{\mathrm{i}}$ [SubjP Hans [MoodP $t_{\mathrm{i}}$ [ObjP die Sonate nicht gespeilt hat]]]] [TopP wahrscheinlich

[TopP sorgfältigerweise ${ }_{i}$

[ModP $t_{\mathrm{i}}$

[TopP oft ${ }_{\mathrm{i}}$

$\left[\right.$ ModP $t_{\mathrm{i}}$

[TopP schwerfälligi

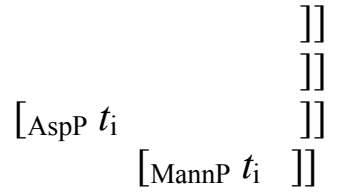

In double object constructions the combinatory possibilities between arguments and adjuncts increase exponentially. As often pointed out in the literature (see Haeberli 1993 and references cited therein), the subject and the objects can scramble in any order, as schematized in (42). ${ }^{6}$

(42) daß \{der Mann/diesen Brief/meinem Onkel\} \{diesen Brief/meinem Onkel/der Mann\} \{meinem Onkel/der Mann/diesen Brief\} gesendet hat.

'that the man sent this letter to my uncle'

A modal adverb like wahrscheinlich 'probably' or a time adverb like gestern 'yesterday' can occupy any position among the arguments in the Mittelfed in (42), as indicated in (43).

b. weil wer wahrscheinlich was nicht gut gespielt hat.

because someone probably something not well played has

'because someone probably did not play something well'

${ }^{5}$ The adverb sorgfälligerweise must have a subject-oriented sentential reading (hence it is root-merged as SpecModP $P_{\text {ability }}$ ).

${ }^{6}$ There are conditions on this kind of scrambling related to specificity (Diesing 1992, de Hoop 1993), as well as focus and pragmatic contexts (Abraham 1986). Note that some German speakers are reticent about free argument scrambling in the sense that they accept a limited number of XP in front of the subject. 
(43) daß (wahrscheinlich/gestern) der Mann/diesen Brief/meinem Onkel (wahrscheinlich/ gestern) diesen Brief/meinem Onkel/der Mann (wahrscheinlich/gestern) meinem Onkel/der Mann/diesen Brief (wahrscheinlich/gestern) gesendet hat. 'that probably/yesterday the man sent this letter to my uncle'

The adverbs and complements that precede the subject merge as Specs of recursive topic projections occurring between $\mathrm{CP}$ and SubjP, as represented in (44b) for the example in (44a).

(44) a. weil wahrscheinlich/gestern diesen Brief der Mann meinem Onkel gesendet hat.

b. [CP weil [TopP wahrscheinlich/gestern [TopP diesen Brief [SubjP der Mann [objp meinem Onkel ...]]]]]

As regards scrambling below the subject (i.e. SubjP) I assume that the Mittelfeld contains a pair of unordered object positions (i.e. ObjP) between every adverb-related functional projection, as shown in (45).

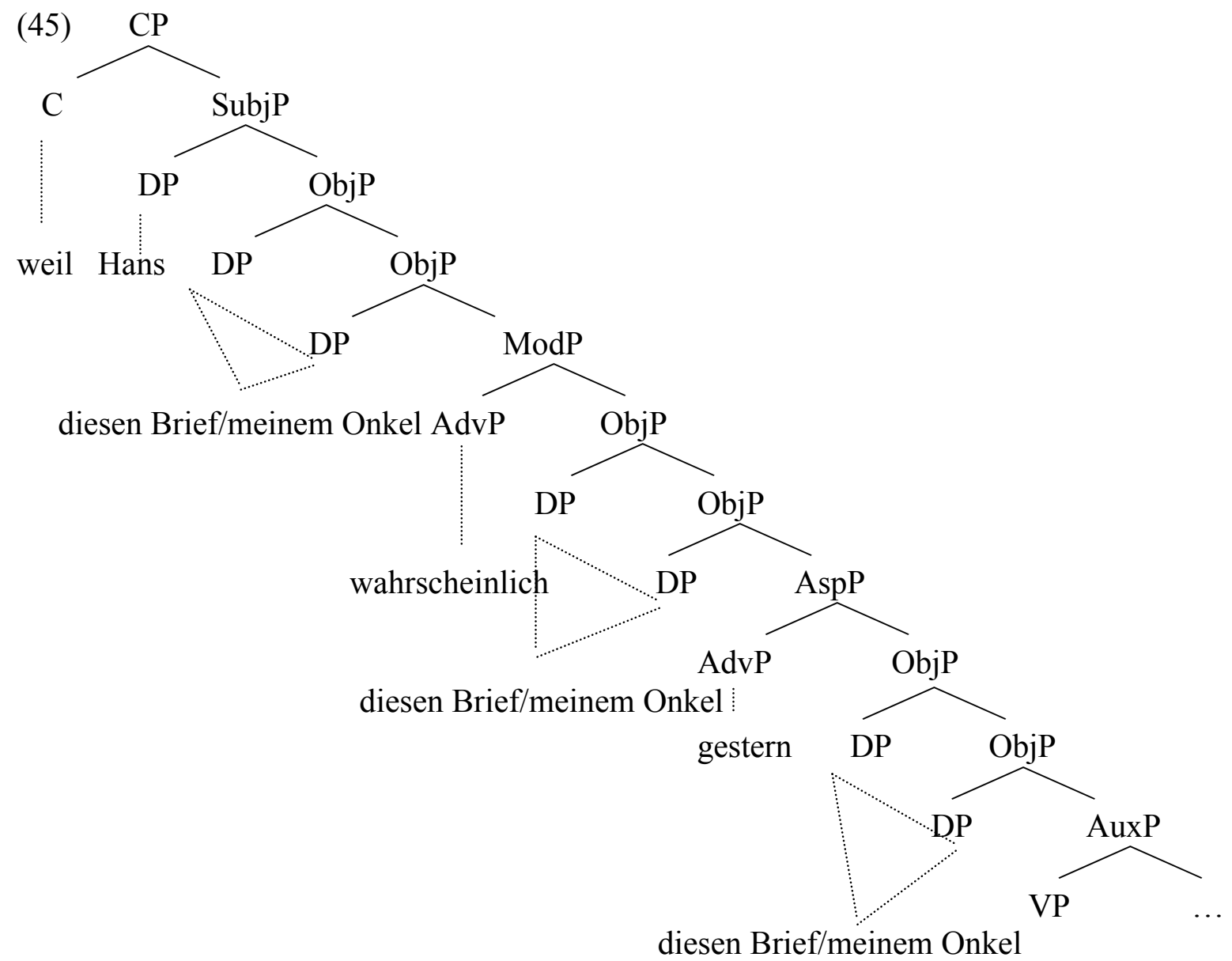

To sum up, the German Mittelfeld is composed of rigid adverb-related functional projections, a fixed subject position, recursive topic projections between the complementizer and the subject position, and unordered object positions between the functional projections.

A series of transformations applies to the German Mittelfeld. The verb moves as a remnant VP to Spec-AuxP/InflP, as in French. The object arguments are extracted from VP and raise to object positions, lower than negation for non-specific DPs, and higher than NegP for specific DPs. Numerous object positions in the Mittelfeld serve as landing sites for 
argument scrambling. Finally, adverbs as well as object arguments can move to a topic domain between the complementizer and the subject position.

French and German share important structural properties, such as the strict hierarchy of functional projections, the fixed subject position, the operation of verb projection raising and the phenomenon of object scrambling. We will see in section 5.1 that a topic projection also occurs in French between the complementizer and the subject to host adverb preposing in relevant contexts.

The next section is devoted to a discussion of adverb distribution in the Nachfeld, i.e. the domain corresponding to the VP-shell structures. The analysis will focus on French and English, since adverbs are not allowed in the Nachfeld in German.

\section{Adverbs in the NaChfeld: The CaSe OF French ANd English}

\subsection{The order [Verb Adverb Complement]}

Following Larson's (1988) VP-shell structure, a verb's arguments all root-merge with the VPshell (Chomsky 1995). The subject merges as Spec-vP, the direct object as Spec-VP and the indirect object as Compl-V. This basic configuration is given in (46). The verbal head (V) raises to $v$ following Chomsky (1995: 315).

$$
\left[{ }_{v \mathrm{P}} \mathrm{SUBJ}\left[{ }^{v+} \boldsymbol{\mathcal { X }}[\mathrm{vp} \mathrm{DO}[\mathrm{v}+\mathrm{V} \mathrm{IO}]]\right]\right]
$$

Contrary to Ernst (2002) I assume that no adverb merges with the VP-shell structure, which delimits the verb's thematic domain. ${ }^{7}$ Adverbs are confined to a functional domain going from $v \mathrm{P}$ (not included) to SubjP (not included). MannP is the functional projection which is the nearest to $v \mathrm{P}$ (for manner adverbs). As proposed in section 3.1, the verb raises as $v \mathrm{P}$ to AuxP/InflP, after the arguments have been extracted from the VP-shell structure. The subject raises to Spec-SubjP, while the objects move to Spec-ObjP, as represented in (47). ${ }^{8}$

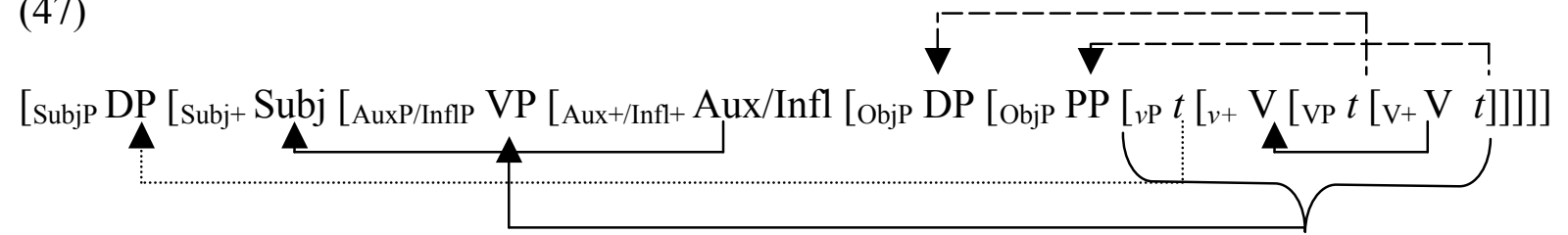

This analysis in terms of remnant/pied-piping VP-movement has the advantage over the analysis in terms of $\mathrm{V}$-movement of accounting for the distribution of adverbs in the Nachfeld. Consider first the intervention of the adverb between the participial verb and its complement(s), as illustrated in (48).

\footnotetext{
${ }^{7}$ In this paper I do not discuss the distribution of DP and PP adverbials, for I consider that they belong to a distributional class different from that of true adverbs (Adv). As proposed by Larson (1985) and Haider (2000), they may be licensed in an (extended) VP-shell structure.

${ }^{8}$ Recal 1 that head-movement is a very constrained transformation: It is confined to the same "categorical" domain, that is, $\mathrm{V}$ to $v$ an Aux/Infl to subj (see section 3.1.1 above).
} 
(48) a. Jean a donné gentiment une pomme (à Marie)

Jean has given kindly an apple (to Marie)

'Jean kindly gave an apple to Mary'

b. Jean a présenté récemment son amie à ses parents.

Jean has introduced recently his (girl)friend to his parents

'Jean recently introduced his (girl)friend to his parents'

As already pointed out in section 3.1, these adverbs can occur in a preverbal position, as in (49).

(49) a. Jean a gentiment donné une pomme (à Marie)

Jean has kindly given an apple (to Marie)

'Jean kindly gave an apple to Mary'

b. Jean a récemment présenté son amie à ses parents.

Jean has recently introduced his (girl)friend to his parents

'Jean recently introduced his (girl)friend to his parents'

The configuration [Aux Adv V Obj] in (49) is obtained after VP-movement to Spec-AuxP situated below TP and ManP, as represented in (50).

(50) ${ }_{\mathrm{CP}}\left[\mathrm{SubjP}\right.$ Jean $\left[\mathrm{Subj}_{+} \mathrm{a}\left[\mathrm{TP}\right.\right.$ récemment $\left[\mathrm{MannP}\right.$ gentiment $\left[\mathrm{AuxP}_{\mathrm{V}}[\mathrm{VP}\right.$ donné] [ObjP une pomme [objp à Marie [vp ]]]]]]]]]

The order [Aux V Adv Obj] in (48) results from remnant VP-movement to a position higher than that of the adverbs, as in (51).

(51) $[\mathrm{CP}[$ Subjp Jean [Subj+ a [Auxp[VP donné] [TP récemment [MannP gentiment [ObjP une pomme [objp à Marie [vP ]]]]]]]]]

The adverbs récemment and gentiment can also be placed between the two objects, as exemplified in (52).

(52) a. Jean a donné une pomme gentiment à Marie.

Jean has given an apple kindly to Marie

'Jean gave an apple kindly to Mary'

b. Jean a présenté son amie récemment à ses parents.

Jean has introduced his (girl)friend recently to his parents

'Jean recently introduced his (girl)friend to his parents'

The configuration [Aux V Obj $j_{\text {direct }} \mathrm{Adv} \mathrm{Obj}_{\text {indirect }}$ in (52) arises from movement of the direct object to an object position situated higher than the functional projections hosting the adverbs. This is represented in (53). ${ }^{9}$

\footnotetext{
${ }^{9}$ High aspectual adverbs behave in the Nachfeld in the same way as time and manner adverbs, as in (i). In contrast, negation and measure (low aspectual) adverbs are prohibited in that domain, as shown in (ii)-(iii). For mood and mode adverbs, the only acceptable position in the Nachfeld is between the verb and the first complement, as in (iv). Finally, "light" adverbs like the manner bien 'well' may not occur in the Nachfeld, as shown in (v).
}

(i) Jean a donné (souvent/de nouveau) une pomme (souvent/de nouveau) à Marie. Jean has given often/again an apple often/again to Marie 
(53) $\left[\mathrm{CP}\left[\right.\right.$ SubjP Jean $\left[\mathrm{Subj}_{+} \mathrm{a}[\mathrm{AuxP}[\mathrm{VP}\right.$ donné $[$ ObjP une pomme [TP récemment [MannP gentiment [Objp à Marie [vP ]]]]]]]]]

The two complements can permute in the Nachfeld, especially if the DO is indefinite (see Belletti \& Shlonsky 1995 for the focus condition on the order IO $<$ DO). This is illustrated in (54a). The possibility of DO-IO/IP-DO permutation is due to the unordered character of ObjP projections, as in German. This is represented in (54b).

(54) a. Jean a donné gentiment à Marie une pomme.

Jean has given kindly to Marie an apple

'Jean kindly gave Mary an apple'

b. [SubjP Jean [Subj a [AuxP [VP donné] [ManP gentiment [objp une pomme/à Marie [objp à Marie/une pomme...]]]]

As expected, an adverb can intervene between the two inverted complements, as in (55a). This means that the Obj positions within the Mittelfeld can host either the direct object or the indirect object, as represented in (55b).

(55) a. Jean a donné à Marie gentiment/récemment une pomme.

Jean has given to Marie kindly/recently an apple

b. [SubjP Jean [Subj a [AuxP [vP donné] [objp à Marie/une pomme [ManP gentiment

[objp une pomme/à Marie...]]]]

From a comparative point of view English differs from French in the so-called adjacency constraint on Case assignment (Stowell 1981). As shown in (56a), an adverb may not intervene between the verb and the direct object DP in English, as opposed to the corresponding French sentence in (48). By contrast, the adverb may intervene between the verb and the complement when the latter is a prepositional phrase, as in (56b).

(ii) Jean n'a donné (*pas) une pomme (*pas) à Marie.

Jean neg-has given not an apple not to Marie

(iii) Jean a lu (*beaucoup) la Bible (*beaucoup) à ses enfants.

Jean has read a lot the Bible a lot to his children

(iv) Jean a donné (évidemment/probablement) une pomme (*évidemment/probablement) à Maire.

Jean has given evidently/probably an apple evidently/probably to Marie

(v) Jean a lu (*bien) un livre (*bien) à Marie.

Jean has read well a book well to Marie

The placement of frequency adverbs in the Nachfeld can be analyzed in the same way as (51) and (53), namely: the adverb-related functional projection (AspP) can be dominated by an AuxP/InflP projection hosting the VP and by an ObjP projection hosting the object. As for mood and mode adverbs, their corresponding functional projection is dominated only by a projection hosting VP, not by an ObjP. Finally, NegP and AspP measure are dominated by none of these projections. Thus, the complete derivational possibilities are represented in (vi).

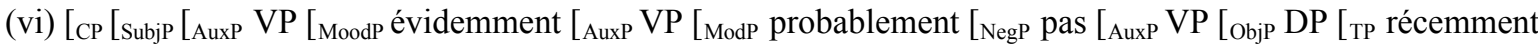
$\left[_{\text {AuxP }}\right.$ VP [objp DP [AspPhigh fréquemment [AuxP VP [AspPlow beaucoup [AuxP VP [objP DP [MannP gentiment [AuxP ...

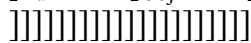

The "light" adverbs ("lite adverbs" in Ernst's (2002) terms; see also Laenzlinger (1998:94)), such as bien and mal, must incorporate to the verb after Spell-Out. Therefore, they must occur in the neighborhood of the verb, i.e. be adjacent to the VP. This incorporation requirement accounts for their very restricted behavior. 
(56) a. John has given * gently/* recently an apple (to Mary).

b. John has spoken gently/recently to Mary.

In section 3.1, I assumed that VP and object complements remain in their root positions in English, as represented in (57a). In such a configuration there is no position for an adverb to intervene between $\mathrm{V}$ and the direct object in Spec-VP. However, the intervention of the adverb between the verb and the PP is not expected from the structure in (57a). Therefore, I assume that the indirect object PP may be extracted from VP under some circumstances and the VP containing the verb and the adjacent direct object DP may raise to Spec-Aux situated above the adverb-related functional projection, as represented in $(57 \mathrm{~b}){ }^{10}$

(57) a. [vp given [vp [DP an apple] [pp to Mary]]

b. [AuxP [vP given [vP [DP an apple]]] [TP/MannP recently/gently [ObjP [pP to Mary] [vP $t]]]]$

There are also differences between French and Italian as to the classes of adverbs that can occur near the participle within the Mittelfeld. Consider the following paradigm.

(58) a. Jean a probablement/souvent/gentiment résolu tes problèmes.

Jean has probably/ often/ gently solved your problems

b. Jean a résolu probablement/souvent/gentiment tes problèmes.

Jean has solved probably /often /gently your problems

'Jean probably/often/gently solved your problems'

c. Gianni ha ${ }^{o k}$ probabilmente/*spesso/ ${ }^{o k}$ gentilmente risolto i tuoi problemi.

d. Gianni ha risolto * probabilmente $/{ }^{\circ \mathrm{k}} \mathrm{spesso} /{ }^{\mathrm{ok}}$ gentilmente i tuoi problemi.

(cf. Gianni ha ${ }^{\mathrm{ok}}$ probabilmente risolto ${ }^{\mathrm{ok}} \mathrm{spesso} /{ }^{\mathrm{ok}}$ gentilmente i tuoi problemi)

The order [Aux Adv V] in (58a), which also holds for English (e.g. John has probably often gently solved your problems), is derived for VP-raising to Spec-AuxP situated below the adverb-related functional projections. In (58b) VP-raising applies to a domain higher than

\footnotetext{
movement, which must be distinguished from true cases of rightward extraposition, as illustrated in (i).

(i) a. Jean a donné hier / ce matin un livre à Marie.

Jean has given yesterday/this morning a book to Marie

b. John read recently/yesterday a very nice book that deals with linguistics.

c. John talked yesterday/this morning to Mary.

d. Jean parlait hier/ce matin à Marie.
}

${ }^{10}$ So far the sequence [(Aux) V Adv Compl] has been analyzed as an instance of remnant pied-piping VP-

The sentence in (ia) differs from (48a) in that the pronoun en cannot be extracted from the object direct DP, as shown by the following contrast: *Jean en a donné hier un [e] 'Jean gave one of it yesterday' vs. ${ }^{\mathrm{ok}} J e a n$ en a donné récemment/gentiment un [e] 'Jean recently/kindly gave one of it'. This contrast can be explained by the different position of the direct object DP in the two structures. In (48a) the direct object DP occurs in a leftward canonical Obj position within the Mittelfeld, a kind of "properly governed" position in GB terms. The extraposition in (ia) is presumably not a syntactic leftward transformation, but a rightward PF-transformation (see Ernst 2002:226ff), and no syntactic extraction can apply in the PF-component. Similarly, the well-known case of Heavy NP-shift in (ib) is a post-Spell-Out phenomenon, which is not subject to the syntactic adjacency constraint invoked for (56b). The intervention of the strong adverbial (of DP category) in (ic-d) also results from rightward PF-extraposition. The extraposed PP stands for a barrier to extraction, as shown by the following case of preposition stranding in English: *Who did you talk yesterday/this morning to [e]? vs. ${ }^{\mathrm{ok}}$ Who did you talk recently/gently to $[e]$ ? 
these functional projections. ${ }^{11}$ In Italian the possibilities of VP-raising vary according to the adverb-related functional projection involved. As shown in (58d), VP-raising cannot apply to a domain higher than ModP, while it can apply to domains higher than $\mathrm{AspP}_{\text {frequency }}$ and MannP. Following (58c) the VP can raise to a position below ModP and MannP, but not below $\mathrm{AspP}_{\text {frequency. }}$ The derivation possibilities for VP-raising in Italian are represented in (59).

(59)...[SubjP [* ${ }^{*}$ AuxP [ModP probabilmente [AuxP [VP risolto] [AspP Spesso [* ${ }^{*}$ AuxP [MannP gentilmente [AuxP [vP risolto...]

Thus, the parametric difference between French and Italian lies in the possibility of VPraising to AuxP in specific domains in the Mittelfeld. In French these domains are identified as a functional space between every adverb-related functional projections, whereas in Italian AuxP is confined to a domain between ModP and AspP, and between MannP and VP. ${ }^{12}$

To end this section, let us examine the case of mirror image order of adverbs, as in (60b), in comparison with the left-to-right linear order in (60a) derived from Cinque's hierarchy.

(60) a. Jean a souvent gentiment donné une pomme à Marie.

Jean has often gently given an apple to Marie

'Jean often gently gave an apple to Mary'

b. Jean a gentiment donné souvent une pomme à Marie.

Jean has gently given often an apple to Marie

The adverbs in (60a) merge as Spec of their corresponding functional projection, while the verb raises as a remnant VP to AuxP above the adverb-related functional projections. The mirror image sequential order in (60b) derives from a kind of "snowballing" pied-piping XPmovement. It is not the VP category that raises to AuxP above AspP, but the MannP category, as represented in (61). Note that before MannP raising the objects have been extracted from VP to "scrambling" object positions occurring between MannP and AspP.

(61) [SubjP Jean [Subj+ [Subj a] [AuxP [MannP gentiment donné] [AspP Souvent [Objp une pomme [Objp à Marie [MannP $t]$ ]]]]]]

This kind of pied-piping XP movement will be further discussed in the next section, which deals with the distribution of adverbs in sentence-final position, i.e. on the right of complements.

\subsection{Sentence-final adverbs}

The examples in (62) involve a time adverb, an aspectual adverb and a manner adverb in a sentence-final position.

\footnotetext{
${ }^{11}$ This is impossible in English due to the adjacency constraint on DP ${ }_{\text {accusative. }}$ E.g. *John has solved probably/ often/kindly your problems.

${ }^{12}$ This parametric difference between French and Italian does not seem to result from morphological properties of the verb. Rather, it looks like an idiosyncratic property of AuxP.
} 
(62) a. Jean a lu un livre récemment.

Jean has read a book recently

'Jean read a book recently'

b. Jean a lu la Bible souvent.

Jean has read the Bible often

'Jean read the Bible often'

c. Jean a embrassé Marie tendrement.

Jean has kissed Marie tenderly

'Jean kissed Marie tenderly'

Mood and mode adverbs cannot occur in a sentence-final position, unless they are parentheticals $^{13}$, as in (63a-b), while low aspectual and light adverbs cannot occupy this position, even in their parenthetical use, as shown in (63c-d).

(63) a. Jean n'a pas lu la Bible, heureusement.

Jean neg-has not read the Bible fortunately

'Jean did not read the Bible, fortunately'

b. Jean a lu la Bible, probablement.

Jean has read the Bible probably

'Jean read the Bible, probably'

c. Jean a lu la Bible *(,)beaucoup.

Jean has read the Bible a lot

'Jean read the Bible a lot'

d. Jean a embrassé Marie *(,)bien.

Jean has kissed Marie well

'Jean read the Bible well'

The adverbs in (62) surface in a sentence-final position after VP-raising to Spec-AuxP and object raising to Spec-ObjP in a domain higher than the relevant adverb-related functional projections. This is represented in (64). ${ }^{14}$

(64) ${ }_{\text {SubjP }}$ Jean a $[$ Auxp $[\mathrm{vP}$ lu] [objP la Bible [TP récemment [AspP souvent [MannP tendrement $[\mathrm{vP}]]]]]]]$

As indicated by the ungrammaticality of $(63 \mathrm{c}-\mathrm{d})$, the verb and its object cannot raise past functional projections hosting low aspectual and light adverbs (cf. *Jean a lu la Bible beaucoup/bien à Marie 'Jean read the Bible a lot/well to Marie'). Thus, these adverbs are not expected in sentence-final position. ${ }^{15}$

\footnotetext{
${ }^{13}$ The analysis of adverbial parentheticals will not be taken into account in this paper. As noted by Jackendoff (1972), McCawley (1982), Laenzlinger (1993), Alexiadou (1997), Ernst (2002), the use of parentheticals can affect, if not violate, the hierarchy of adverbs within the clause. Following Ernst (2002) we can suppose that parenthetical insertion is a (downward/rightward) PF-phenomenon, which is not subject to Kayne's LCA and Cinque's adverb hierarchy.

${ }^{14}$ Alternatively, the verb and the direct object can move together as a VP to AuxP. However, I have adopted an analysis of verb projection raising that applies independently of object raising in order to deal with the cases of adverb intervention between the verb and the raised object(s) (e.g. Jean a embrassé souvent Marie tendrement 'Jean (has) often kissed Marie tenderly').

${ }^{15}$ As far as the light adverb bien is concerned, it cannot occur in the Nachfeld, because it has to incorporate to the verb after Spell-Out (see section 4.1). As regards the measure adverb beaucoup, its very restricted distribution remains mysterious (it cannot be considered a light adverb).
} 
As exemplified in (65), more than one adverb can occur on the right of the complement(s), either in a linear order respecting Cinque's hierarchy $((65 a-b))$ or in a mirror image order ((65c-d)).

(65) a. Jean a embrassé Marie souvent tendrement.

Jean has kissed Marie often tenderly

'Jean kissed Marie often tenderly'

b. Jean a mangé une pomme parfois entièrement.

Jean has eaten an apple sometimes entirely

'Jean sometimes ate an apple entirely'

c. Jean a mangé une pomme entièrement récemment.

Jean has eaten an apple entirely recently

'Jean recently ate an apple entirely'

d. Jean lira la Bible (attentivement) souvent maintenant.

Jean will-read the Bible carefully often now

'Jean will often read the Bible carefully now'

The linear order of adverbs (65a-b) results from VP-raising to AuxP and object movement to ObjP past the two adverb-related projections (AspP and MannP), as represented in (66).

(66) a. [SubjP Jean a [AuxP [vp embrassé] [ObjP Marie [AspP souvent [MannP tendrement $[\mathrm{vP} \ldots]]]]]]$

b. [SubjP Jean a [AuxP [VP mangé] [ObjP Une pomme [AspP parfois [AspP entièrement $[\mathrm{vP} \ldots]]]]]]$

The mirror image order in (65c-d) derives from pied-piping (i.e. snowballing) movement of the projection containing the right-hand adverb, the verb and its object. The derivation for (65c) is given in (67). The projection AuxP containing the raised VP (mangé), the object (une pomme) and the adverb entièrement moves to a functional position immediately above TP. 
(67)

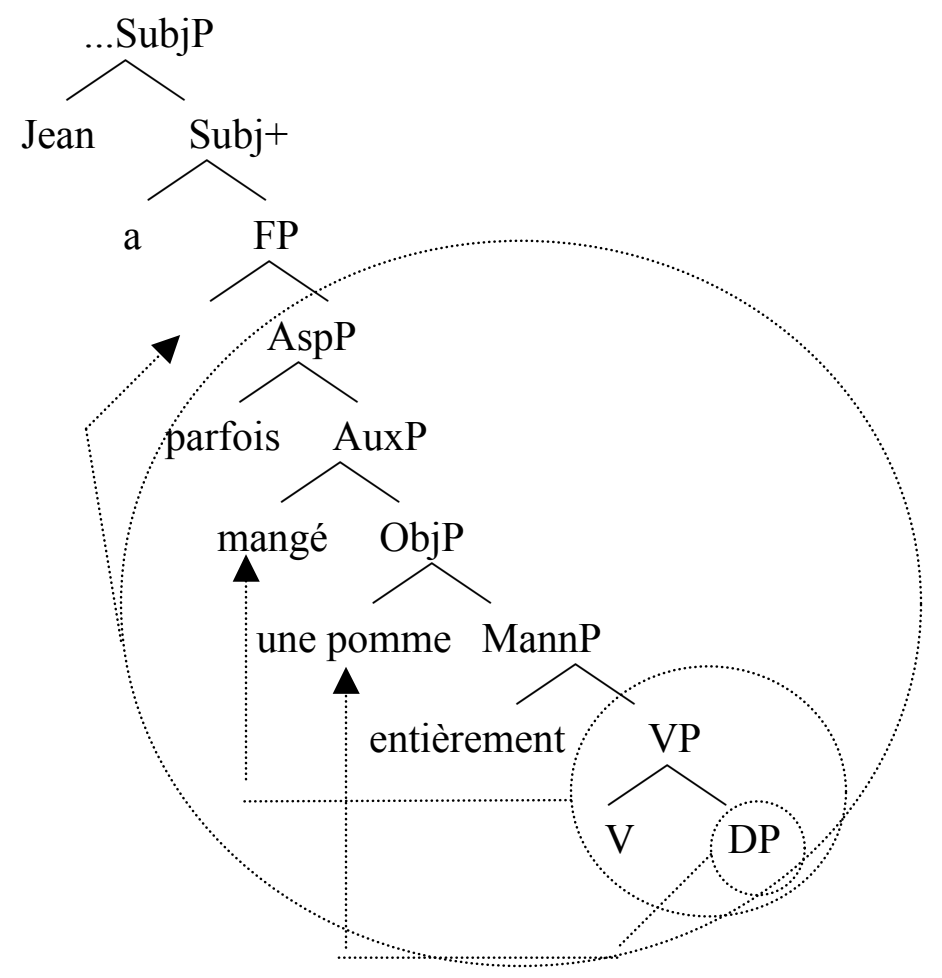

This kind of pied-piping movement can apply successively with snowballing effects, as illustrated in (65d). The sentence-final order attentivement $<$ souvent $<$ maintenant results from a two-step pied-piping movement (ObjP raising followed by FP raising), as represented in (68). The verb in simple tense raises as VP to Spec-InflP immediately below SubjP, while the direct object moves as DP to Spec-ObjP immediately above MannP. ${ }^{16}$

\footnotetext{
${ }^{16}$ This type of analysis can account for the scope ambiguity displayed by the sentence-final adverbs in (i) below. Provided that scope can be computed at any step of the derivation (by any member of the chain following the Scope Principle in Ernst (2002:317)) under c-command, the adverb intentionnellement has scope over deux fois at the root (Cinque's hierarchy), while after pied-piping "snowballing" movement the adverb deux fois has scope over intentionnellement. In comparison, the adverbs in (ii) do not display scope ambiguity. The scope relation intentionnellement $>$ deux fois derives from Cinque's hierarchy, namely $\mathrm{ModP}_{\text {volitional }}>\mathrm{AspP}_{\text {measure, }}$ which is preserved during the derivation.

(i) Il a frappé à la porte deux fois intentionnellement he has knocked on the door twice deliberately 'He knocked on the door twice deliberately' (ambiguous : [deliberately [twice]] or [twice [deliberately]])

(ii) Il a frappé à la porte intentionnellement deux fois. He has knocked on the door deliberately twice 'He knocked on the door twice deliberately' (non ambiguous)
} 


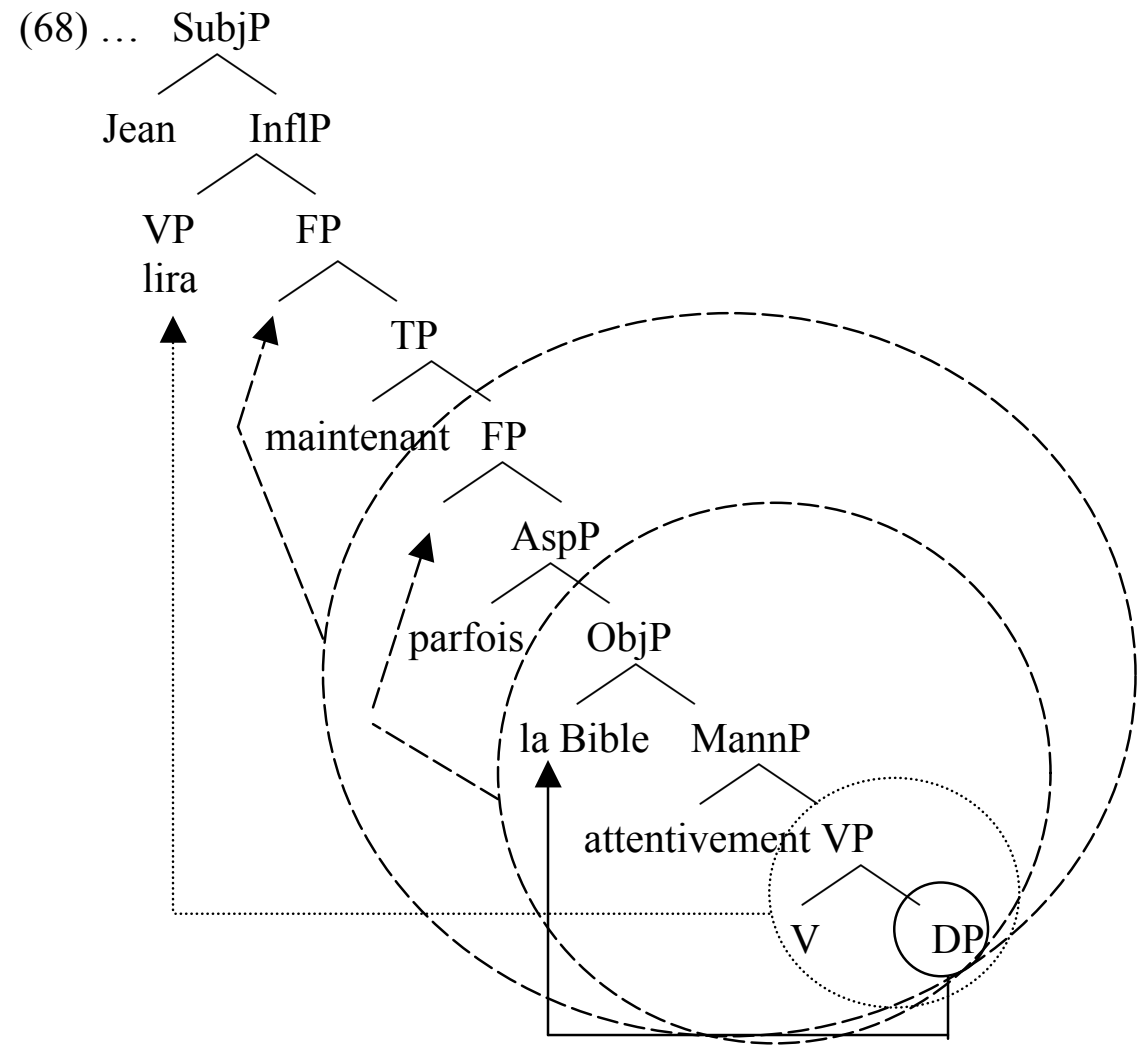

The next section is devoted to the distribution of adverbs in the Vorfeld.

\section{ADVERBS IN THE VORFELD}

\subsection{The order [Adv Subj V] vs. [Subj Adv V] in Romance and English}

Adverb preposing is relatively frequent in French. As topics they can merge as Spec of TopP in the split CP structure (Rizzi 1997), as in (69). ${ }^{17}$

\footnotetext{
Criterion, are "frozen" in their checking position.

(i) a. *Beaucoup, Jean a lu la Bible.

Much Jean has read the Bible

b. *Presque, Jean a mangé sa soupe.

Almost Jean has eaten his soup

c. *Bien, il a mangé sa soupe.

Well he has eaten his soupe

d. *Entièrement, Jean a lu ce livre. Entirely Jean has read this book
}

${ }^{17}$ As already mentioned in section 3.2, adverb topicalisation cannot involve quantificational adverbs, i.e. true operators, as shown by the ungrammaticality of (ia-b). These operators, once they have satisfied the Adv-

Light adverbs like bien in (ic) cannot be topicalized, since they must be adjacent to the verb in order to incorporate to it after Spell-Out. The problem in (id) lies in the predication requirement on the adverb: entièrement must be in a local c-command relation with the object (i.e. the entire book). The adverb in (id) does not stand in such a local configuration with the direct object (cf. ${ }^{\text {ok }}$ Entièrement, ce livre a été lu 'Entirely this book has been read'). Likewise, the adverbs in (i) cannot be focalized (i.e. moved to FocP), as shown in the cleft/focused sentences in (ii), for the same reasons as they cannot be topicalized: Quantificational adverbs are frozen in their clause-internal position, light adverbs require an adjacency configuration with the verb, and object-oriented adverbs need to be in a local relation with the object of the verb. 
(69) a. (Je sais que,) [Topp probablement, [Subjp Jean a salué le professeur]]

b. [TopP Amicalement, [FocP qui as-tu salué?]]

The adverbs in (69a-b) occupy a fronted topic position above the subject position. ${ }^{18}$ Presumably, this is also the case in the English sentence in (70).

\section{[TopP Probably/amicably [SubjP John will greet the professor]]}

In French these 'high' adverbs may not intervene between the subject and the tensed verb/auxiliary, unless they are parentheticals, as shown by the contrast between $(71 a-b)$ and (71c-d) involving the modal adverb.

(71) a. *Jean probablement/amicalement saluera le professeur. Jean probably amicably will-greet the professor

b. *Jean probablement/amicalement a salué le professeur. Jean probably amicably has greeted the professor

c. Jean, probablement/amicalement, saluera le professeur. 'Jean probably/amicably will greet the professor'

d. Jean, probablement/amicalement, a salué le professeur. 'Jean probably/amicably greeted the professor'

In English, however, these adverbs may occur between the subject and the tensed verb/auxiliary, as in (72).

(72) a. John probably/amicably greeted the professor.

b. John probably/amicably will greet the professor.

The difference between (71a) and (72a) lies in the application of VP-raising to InflP in French (i.e. adjacency between VP in Spec-InflP and SubjP), but not in English. Hence, any clauseinternal adverb can intervene between the subject and the verb in English (e.g. John gently left). As regards (71b), an adverb cannot intervene between the subject in Spec-SubjP and the verb, because the latter raises to Subj (cf. [Subjp Jean [Subj $a$ ] [ModP probablement dormi]] 'Jean has probably slept'). As for (72b), one is led to assume that the modal may, but must not, raise to Subj : [Subjp John [Subj will] [ModP probably leave]] vs. [SubjP John [Subj] [ModP probably will leave]]. Similar facts are observed in Italian, Spanish and Portuguese, as illustrated in (73a), (73b) and (73c) respectively.

(ii) a. *C'est [Focp beaucoup qu' il a lu la Bible] / *[FocP BEAUCOUP, il a lu la Bible] It is much that he has read the Bible / MUCH he has read the Bible

b. *C'est [FocP presque que Jean a mangé sa soupe ]/ * [FocP PRESQUE, Jean a mangé sa soupe] It is almost that Jean has eaten his soup / ALMOST Jean has eaten his soup

c. ${ }^{*}$ C'est [FocP bien qu' il a mangé sa soupe] / *[FocP BIEN, il a mangé sa soupe]

It is well that he has eaten his soup / WELL he has eaten his soup

d. *C'est [FocP entièrement qu' il a lu ce livre / *[FocP ENTIEREMENT, il a lu ce livre] It is entirely that he has read this book/ ENTIRELY he has read this book

18 This kind of topicalisation differs from the topic-comment relation observed by Rizzi (1997) for clitic left dislocation (see also Cinque 1990). Rizzi (2002) refers to it as a case of "structural prominence". I still assume that the fronted adverbs in (69) and (70) occupy a topic position labeled TopP. 
(73) a. Gianni probabilmente/spesso telefonerà alle 5.

(cf. Gianni probably/often will phone at 5)

Gianni probabilmente/spesso ha telefonato alle 5.

(cf. Gianni probably/often has phoned at 5)

b. Juan probablemente/a menudo llamará a las cinco.

Juan probablemente/a menudo ha llamado a las cinco.

c. O João provavelmente/frequentemente telefonara as 5 da tarde.

O João provavelmente/frequentemente teria telefonado as 5 da tarde

In Romance the tensed verb/auxiliary is supposed to raise to a position adjacent to the subject, say Subj. Therefore, the intervention of an adverb between the subject and the raised verb is not expected. As far as the Italian sentences in (73a-b) are concerned, Belletti (1990) shows that the subject is topicalized, since it is incompatible with a negative quantifier: *Nessuno probabilmente/spesso telefonera. Thus, the subject Gianni in (73a) is topicalized as SpecTopP in the Comp domain, which leaves enough space for the insertion of an intervening adverb, either in Spec-ModP/AspP or Spec-TopP. ${ }^{19}$ In $(72 b)$ and $(73 b-c)$ the subject is not topicalized, since a negative quantifier is possible as in these constructions, as for instance in English: nobody probably/often will phone at 5. The subject occurs in its canonical position, identified as Spec-SubjP, and the adverbs occupy the specifier position of their semantically related functional projection. The configuration [Subj Adv V/Aux] is obtained after verb projection raising to a position lower than the adverb-related functional projections, as represented in (74).

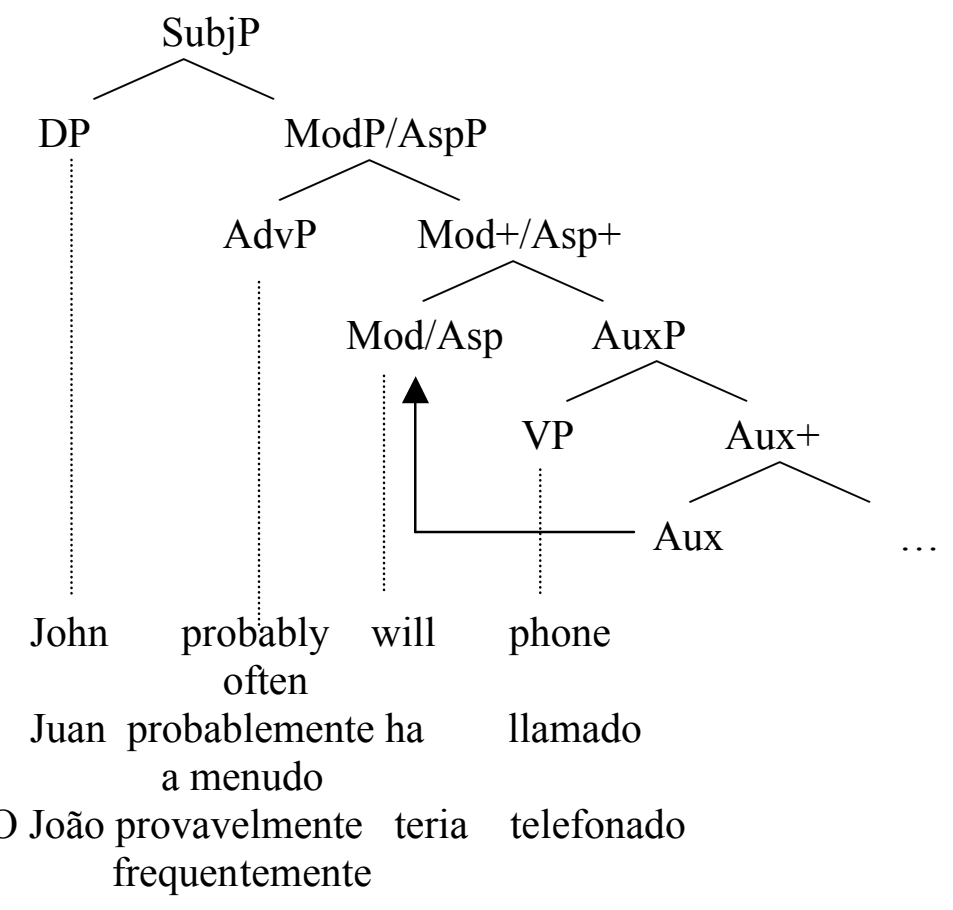

\footnotetext{
${ }^{19}$ If the adverb occurs in Spec-ModP/AspP, the structure assigned to (73a) is given in (i). If the adverb occurs in Spec-TopP, the resulting structure is the one in (ii).

(i) [TopP Gianni $\mathrm{i}_{\mathrm{i}}\left[\mathrm{Subjp}_{\mathrm{P}} t_{\mathrm{i}}[\mathrm{ModP} / \mathrm{AspP}\right.$ probabilmente/spesso [telefonerà/ha telephonato alle 5]]]]

(ii) $\left[\right.$ TopP Gianni $_{i}\left[{ }_{\mathrm{TopP}}\right.$ probabilmente/spesso $\left[\mathrm{Subjp}_{\mathrm{P}} t_{\mathrm{i}}\right.$ [telefonerà/ha telephonato alle 5]]]]

The structure in (i) is related to the sentence Gianni telefonerà probabilmente/spesso alle 5, while the structure in (ii) is related to the construction Probabilmente/spesso Gianni telefonerà alle 5.
} 
The next section deals with the very restricted distribution of adverbs in the German Vorfeld, in relation to the V2 constraint and remnant VP-topicalisation.

\subsection{Adverbs in the German Vorfeld}

In German adverbs can be preposed in the CP domain, either as a topic or as a focus. In these cases the verb must be placed in the second position of the clause after the AdvP constituent, as illustrated in (75a-b) with a topic and a focal adverb. The V2 constraint is straightforwardly accounted for by Kayne's (1994) LCA theory of phrase structure. ${ }^{20}$ The first constituent of the clause occupies Spec of $\mathrm{CP}$, while the tensed verbal form is raised to $\mathrm{C}^{21}$

(75) a. [CP Oft [C hat] [SubjP Hans dieses Buch gelesen]] often has Hans this book read

'Often Hans read this book'

b. [CP GESTERN [C hat] [Subjp Hans dieses Buch gelesen]] yesterday has Hans this book read

'Yesterday Hans read this book'

Most interestingly, adverbs can also occur in the Vorfeld by means of a transformation called "Remnant VP-topicalisation", which brings along the participial verb and eventually some constituent(s) of the Mittelfeld to a fronted position, as in (76). In the Principles \& Parameters framework VP-topicalisation is treated as an instance of remnant and/or piedpiping VP-movement to Spec-CP (see den Besten \& Webelhuth 1990, Haider 1993 among others) with the tensed auxiliary in C (V2).

(76) a. [CP Das Buch nicht gelesen [C hat] [SubjP Hans gestern]] the book pas read has Hans yesterday

'Read the book Hans did not yesterday'(?)

b. [CP Gelesen [C hat] [Subjp Hans das Buch gestern]] read has Hans the book yesterday

'Read the book Hans did yesterday'(?)

According to (77a-e) VP-adverbs and event-related adverbs can be fronted with the participial verb and the scrambled direct object, whereas sentential-adverbs, as in (77f), cannot be involved in pied-piping VP-topicalisation. Adverbs can be used as clues for identifying the categorical status of the FP projection involved in (77).

\footnotetext{
${ }^{20}$ The approach to V2 adopted here is syntactic, not phonological (PF). In other words, the V2 constraint is a specific structural condition on the CP domain in Germanic.

${ }^{21}$ No further adjunction is allowed to CP, as shown by the ungrammaticality of (ia-b).

(i) $\quad$ a. $*\left[{ }_{\mathrm{CP}}\right.$ Gestern $[\mathrm{CP}$ Hans $[\mathrm{C}$ hat $]$ dieses Buch gelesen $\left.\left.]\right]\right]$ yesterday Hans has this book read

b. $\quad *_{[\mathrm{CP}}$ Oft [CP dieses Buch [C hat] Hans gelesen]]

often this book has Hans read
} 
(77)
a. $\quad[\mathrm{CP}[\mathrm{FP}$ Die Sonate gut gespielt $][\mathrm{C}$ hat $]$ Hans $]$
The sonata well played has Hans
'Play the sonata well Hans did'
b. [CP [FP Schnell die Sonate gespielt] [C hat] Hans]
Quickly the sonata played has Hans
'Quickly play the sonata Hans did'
c. [CP [FP Gern die Sonate gespielt] [C hat] Hans]
Willingly the sonata played has Hans
'Willingly play the sonata Hans did'
d. [CP [FP Gestern/kürzlich die Sonate gespielt] [C hat] Hans]
Yesterday/recently the sonata played has Hans
'Play the sonata recently/yesterday Hans did'
e. $\quad[\mathrm{CP}[\mathrm{FP}$ Oft die Sonate gespielt $]$ [C hat] Hans]
Often the sonata played has Hans
'Often play the sonata Hans did'
f. $\quad *$ [CP [FP Leider/glücklicherweise/vielleicht die Sonate gespielt] [C hat] Hans] Un-/fortunately maybe the sonata played has Hans

The borderline for VP-topicalisation can be identified as the functional projection immediately below ModP. Thus, any clause-internal projection below ModP can be fronted. For instance, in (76b) the projection that is topicalized contains only the participle. It can be identified as the VP (or the AuxP) from which the object has been extracted. In (76a) the topicalized projection, which contains the scrambled object and negation, can be equated with the ObjP immediately above NegP. As for (76a-e), the displaced FP constituent can be identified as a functional projection below ModP containing the participle, the direct object and the relevant adverb. Any clause-internal projection below ModP can be potentially topicalized in Spec-CP, as represented in (78). ${ }^{22}$

22 As expected from (78), VP-topicalisation can involve solely the adverbs or solely the direct object, as shown
in (i) and (ii).

(i) a. [CP $_{\mathrm{FP}}$ Gut/schnell/gern/gestern/kürzlich/oft gespielt] [C hat] Hans die Sonate] well/quickly/willingly/yesterday/recently/often played has Hans the sonata

b. $\quad *_{\text {CP }}[\mathrm{FP}$ Leider/glücklicherweise/vielleicht gespielt] [C hat] Hans die Sonate] unfortunately/happily/maybe played has Hans the sonata

(ii) a. [CP [FP Die Sonate gespielt $][\mathrm{C}$ hat $]$ Hans gut/schnell/gern/gestern/kürzlich] the sonata played has Hans well/quickly/willingly/yesterday/recently

b. [CP [FP Die Sonate gespielt] [C hat] Hans leider/glücklicherweise/vielleicht] the sonata played has Hans unfortunately/happily/maybe

(ib) is ungrammatical, since no projection above TP can raise to Spec-CP. In short, any ObjP and adverb-related functional projection below ModP in (78) is allowed to topicalize in Spec-CP. In double object constructions the two complements can be fronted with the participle, as in (iii), or only one of the two objects, as in (iv-v). As regards the adverbs, only those licensed below ModP can be raised to CP. The analysis of (iii)-(v) is based on the assumption that any ObjP (see structure (45)) and adverb-related functional projection below ModP can be topicalized in Spec-CP.

(iii) *Leider/ ${ }^{\mathrm{ok}}$ gestern/ ${ }^{\mathrm{ok}}$ oft/ ${ }^{\mathrm{ok}}$ gern dieses Buch dem Jason geschenkt hat sie. Unfortunately/yesterday/often/willingly this book the $\mathrm{dat}_{\mathrm{J}}$ Jason offered has she

(iv) $*$ Leider $/{ }^{\circ \mathrm{k}}$ gestern $/{ }^{\mathrm{k}}$ oft $/{ }^{\mathrm{ok}}$ gern dieses Buch geschenkt hat sie dem Jason.

(v) $*$ Leider $/{ }^{\circ \mathrm{k}}$ gestern $/{ }^{\circ \mathrm{k}}$ oft $/{ }^{\mathrm{ok}}$ gern dem Jason geschenkt hat sie dieses Buch. 


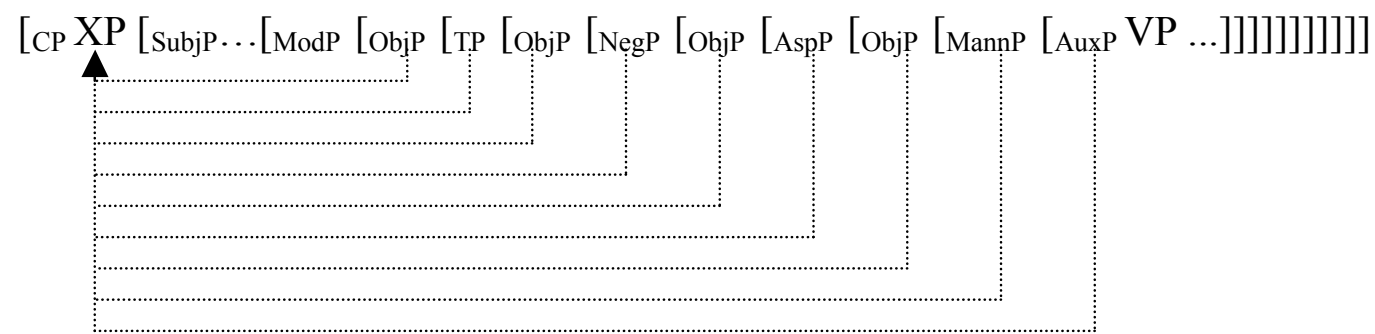

VP-topicalisation can involve more than one adverb, as in (79a-b). In these examples the adverb hierarchy is preserved since the topicalized projection contains an adverb whose position is lower than that of the adverb left behind. Thus, scope can be correctly computed at the level of the trace, that is, in the Mittelfeld. ${ }^{23}$ In contrast, the examples in (79c-d) are ungrammatical, because VP-topicalisation cannot take a functional domain containing a high adverb while leaving a low adverb behind. As shown by the location of the trace in $(79 \mathrm{c}-\mathrm{d})$ such a derivation is impossible according to the constituent structure of the clause. ${ }^{24}$

(79) a. Schnell die Sonate gespielt hat Hans oft $[t]$.

Quickly the sonata played has Hans often

'Quickly play the sonata Hans did often'

b. Sorgfälltig die Sonate gespielt hat Hans nicht $[t]$.

Carefully the sonata played has Hans not

'Carefully play the sonata Hans did not'

c. *Oft die Sonate gespielt hat Hans $[t]$ schnell.

Often the sonata played has Hans quickly

d. *Nicht die Sonate gespielt hat Hans $[t]$ sorgfälltig.

Not the sonata played has Hans carefully

To sum up, the Vorfeld in German can host adverbs in first position (Spec-CP) and the verb in second position (C). The fronted adverbs are either topicalized or focalized. Adverbs can also occur in the Vorfeld by means of remnant and pied-piping VP-topicalisation. Formally, any clause-internal functional projection below ModP can be topicalized in SpecCP.

\section{Conclusion}

The question of adverb syntax has been tackled from a comparative point of view by analyzing the distribution of adverbs in French and German within the three domains of the clause: the Vorfeld, the Mittelfeld and the Nachfeld.

\footnotetext{
${ }^{23}$ This analysis fits in well with Chomsky's (1995) Copy Theory of reconstruction phenomena.

24 From a comparative point of view VP-topicalisation in German differs from VP-fronting in English in that event-related adverbs and negation cannot be fronted with the verb in the latter language. As pointed out by Jackendoff (1972), only VP-adverbs can be fronted with the verb in sentence-initial position. This is shown by the contrast between (ia) and (ib). Thus, only functional projections below NegP can be moved to a sentenceinitial position in English, whereas VP-topicalisation in German can involve any functional projection below ModP.
}

(i) a. Painstakingly read the book he has.

b. *Maybe/not/recently read the book he has. 
Adverbs are regarded as unique specifiers of semantically related functional projections (basically MoodP $>$ ModP $<\mathrm{TP}<\mathrm{AspP}$ ). The hierarchy of clause-internal functional projections dictates the hierarchy of co-occurrences of adverbs. In addition to adverb-related functional projections the Mittelfeld structure contains argument-related projections (ObjP) and lexico-functional projections (AuxP, InflP). The VP-shell structure stands for the Nachfeld, while the split-CP layer constitutes the Vorfeld.

I have shown that the clause structure in French and German is assigned the same base of functional projections. The adverbs and the subject have a fixed position within the clause structure. Both German and French display verb projection (VP) raising to AuxP/InflP and argument scrambling. The two languages differ in (i) the range of positions for AuxP/InflP and ObjP (high scrambling for German and low scrambling for French) and (ii) Infl/Aux movement to Subj (in French) and to C (V2 in German). Scrambling movement targets different landing sites in French and German, which accounts for the variations of positioning observed in the two languages among co-occurring adverbs and derived arguments.

When adverbs occur in the Nachfeld in French, their distribution interacts with that of complements. The various positions of adverbs with respect to objects are derived from transformations like object extraction from VP and pied-piping VP-raising. Co-occurring adverbs in the Nachfeld either respect Cinque's hierarchy of functional projections or display the mirror image order of this adverb. The former case results from cyclic object-movement and VP-raising, whereas the latter case derives from "snowballing" pied-piping VP-raising (involving MannP, AspP, etc.). Thus, high adverbs can surface on the right of low adverbs, since their respective scope properties can be recovered by reconstruction. Adverbs do not occur in the Nachfeld in German, because (non-CP) arguments are obliged to scramble past AuxP/InflP.

Finally, the distribution of adverbs in the Vorfeld has been analyzed by means of topicalisation in the left periphery of the clause. Adverbs in the French Vorfeld are structurally prominent (as Spec-TopP). No adverb is allowed to intervene between the subject and the tensed verb/auxiliary, since the former occurs in Spec-SubjP, while the latter raises to Sub. In English, Spanish and Portuguese, the tensed verb/auxiliary does not need to move up to Subj, hence making adverb intervention possible. In Italian, the sequence [Subj Adv V] is analyzed as an instance of subject topicalisation. In German, adverbs can occur in the German Vorfeld as topics in Spec-TopP. They can also surface in the German Vorfeld by means of remnant/pied-piping VP-topicalisation, which consists of raising any clause-internal functional projection lower than ModP to Spec-CP.

\section{REFERENCES}

Abraham, W. (1986) 'Word Order in the Middle Field of the German Clause'. In W.Abraham $\&$ S. de Meys (eds.) Topic, Focus and Configurationality, pp. 15-38. John Benjamins, Amsterdam.

Alexiadou, A. (1997) Adverb Placement : a Case Study in Antisymmetric Syntax. John Benjamins, Amsterdam/Philadelphia.

Belletti, A. (1990) Generalized Verb Movement : Aspects of Verb Syntax. Rosenberg $\&$ Sellier, Turin.

Belletti, A. \& U. Shlonsky (1995) 'The Order of Verbal Complements'. Natural Language and Linguistic Theory 13, 489-526.

Chomsky, N. (1986) Barriers. MIT Press, Cambridge, Mass.

Chomsky, N. (1995) The Minimalist Program. MIT Press, Cambridge, Mass.

Cinque, G. (1990) Types of $\overline{\mathrm{A}}$ Dependencies. MIT Press, Cambridge, Mass. 
Cinque, G. (1999) Adverbs and Functional Heads : a Cross-linguistic perspective. Oxford University Press, Oxford.

de Hoop, H. (1993) Case Configuration and NP Interpretation. Ph.D. dissertation, University of Groningen.

den Besten, H. \& G. Webelhuth (1990) 'Stranding'. In Grewendorf, G. \& W. Sternefeld (eds.) Scrambling and Barriers, pp 72-92. John Benjamins, Amsterdam.

Diesing, M. (1992) Indefinites. MIT Press, Cambridge, Mass.

Ernst, T. (2000) 'On the Order of Event-Internal Adjuncts'. In Alexiadou, A. \& P. Svenonius (eds.) Linguistics in Potsdam, vol 6, pp. 33-49, University of Potsdam, Potsdam.

Ernst, T. (2002) The Syntax of Adjuncts. Cambridge University Press, Cambridge.

Frank, R., Y.-S. Lee \& O. Rambow (1991) 'Scrambling as Non-operator Movement and the Special Status of Subjects. In LCJL3 Proceedings, Leiden, pp. 135-54.

Frey, W. (2000) 'Syntactic Requirement on Adverbs'. In Fabricius-Hansen, C., E. Lang \& C. Maienborn (eds.) Approaching the Grammar of Adjuncts (ZASPIL 17), pp. 107-34, ZAS, Berlin.

Giorgi, A. \& Pianesi (1991) Tense and Aspect: From Semantic to Morphosyntax. Oxford University Press, New York.

Grewendorf, G. \& W. Sternefeld (1990) Scrambling and Barriers. John Benjamins, Amsterdam.

Haeberli, E. (1993) 'Scrambling and Feature Checking'. Geneva Generative Papers 1.2, 26-47.

Haegeman, L. (1995) The Syntax of Negation. Cambridge University Press, Cambridge.

Haider, H. (1993) Deutsche Syntax - Generativ. Gunter Narr, Tübingen.

Haider, H. (2000) 'Adverb Placement - Convergence of Structure and Licensing'. In Alexiadou, A. \& P. Svenonius (eds.) Linguistics in Potsdam, vol 6, pp. 50-77, University of Potsdam, Potsdam.

Jackendoff, R. (1972) Semantic Interpretation in Generative Grammar. MIT Press, Cambridge, Mass.

Kayne, R. (1994) The Antisymmetry of Syntax. MIT Press, Cambridge, Mass.

Koopman, H. \& A. Szabolcsi (2000) Verbal Complexes. Current Studies in Linguistics, 34, MIT Press, Cambridge, Mass.

Laenzlinger, C. (1996) 'Adverb Syntax and Phrase Structure'. In A.-M. di Sciullo (ed.) Configurations: Essays on Structure and Interpretation, pp. 99-127, Cascadilla Press, Somerville, Mass.

Laenzlinger, C. (1998) Comparative Studies in Word Order Variation: Adverbs, Pronouns and Clause Structure in Romance an Germanic. John Benjamins, Amsterdam/ Philadelphia.

Laenzlinger, C. (2000) 'More on Adverb Syntax'. In Alexiadou, A. \& P. Svenonius (eds.) Linguistics in Potsdam, vol 6, pp. 103-32, University of Potsdam, Potsdam

Larson, R. K. (1985) 'Bare NP Adverbs'. Linguistic Inquiry 16, 595-621.

Larson, R. K. (1988) 'On the Double Object Construction'. Linguistic Inquiry 19, 335-392.

May, R. (1985) Logical Form. MIT Press, Cambridge, Mass.

McCawley, J. (1982) 'Parentheticals and Discontinuous Constituent Structure'. Linguistic Inquiry 13, 91-106.

McConnell-Ginet, S. (1982) 'Adverbs and Logical Form: A Linguistically Realist Theory'. Language 58, 144-84.

Moltmann, F. (1991) 'Scrambling in German and the Specificity Effect. Ms. MIT, Cambridge, Mass.

Müller, G. \& W. Sternefeld (1993) 'Improper Movement and Unambiguous Binding'. Linguistic Inquiry 24, 461-507. 
Obenauer, H. (1983) 'On the Identification of Empty Categories'. The Linguistic Review 4, 153-202.

Pollock, J.-Y. (1989) 'Verb Movement, UG and the Structure of IP'. Linguistic Inquiry 20, $365-425$.

Rizzi, L. (1990) Relativized Minimality. MIT Press, Cambridge, Mass.

Rizzi, L. (1991) 'Residual Verb Second and the Wh-Criterion'. Technical Reports in Formal and Computational Linguistics 2, University of Geneva.

Rizzi, L. (1997) 'The Fine Structure of the Left Periphery'. In Haegeman, L. (ed.) Elements of Grammar, pp. 281-337, Kluwer Academic Publishers, Dordrecht.

Rizzi, L. (2002) 'Locality and Left Periphery'. In Belletti, A., (ed.) Structures and Beyond. The Cartography of Syntactic Structures, vol. 3, Oxford University Press. Oxford.

Roberts, I. (1985) The Representation of Implicit an Dethematizied Subjects. Foris, Dordrecht. Rochette, A. (1990) 'The Selectional Properties of Adverbs'. In Ziolkowski, M., M. Noske \& K. Deaton (eds.) CLS 26, vol. 1, pp. 425-445, University of Chicago.

Stowell, T. (1981) Origins of Phrase Structure. Ph.D. dissertation, MIT, Cambridge, Mass. Travis, L. (1988) 'The Syntax of Adverbs'. McGill Working Papers in Linguistics: Special Issue on Comparative Germanic Syntax, 280-310. 